
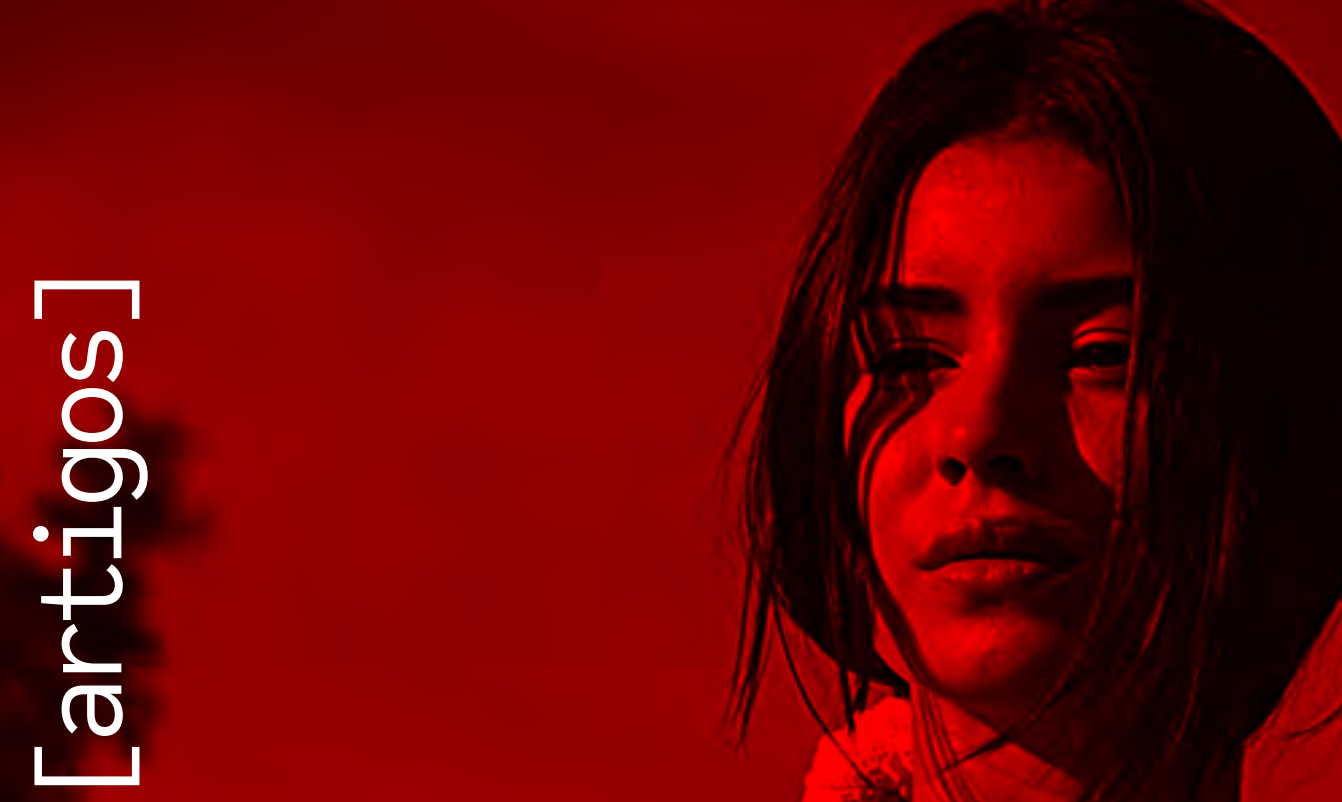


\section{É Vossa Excelência pela adoção da jupe-culotte? Escândalo e modelagem em 1911}

Is your excellency for the adoption of the jupe-culotte?

Scandal and pattern making in 1911 


\section{Fausto Viana ${ }^{1}$}

ORCID: http://orcid.org/0000-0002-4823-3626

\section{Isabel Cristina Italiano ${ }^{2}$}

ORCID: http://orcid.org/0000-0003-4887-7904

[resumo] Em 1911, a metrópole de São Paulo foi invadida, às vésperas da inauguração do Theatro Municipal, por uma nova moda, a jupe-culotte, que já havia assombrado cidades do Velho Mundo, como Roma e Paris. Esse último grito da moda fora ouvido também na então capital federal, o Rio de Janeiro, onde senhoras que usaram o traje precisaram ser conduzidas para escaparem das ruas em segurança. 0 artigo investiga as razões dessa animosidade e oferece ainda ao pesquisador a modelagem da jupe-culotte, feita a partir de manuais de modelagem e revistas de moda do período e em instituição museológica, para uso e recriação artística.

[palavras-chave] Jupe-culotte. Poiret. Diaghilev. Herminia Gonçalves.

[abstract] In 1911, the city of São Paulo was invaded, on the eve of the inauguration of the Municipal Theater, by a new fashion that had already haunted Old World cities such as Rome and Paris. This last cry of fashion had also been heard in the then Federal Capital, Rio de Janeiro, when ladies who wore the costume had to be escorted to escape the streets safely. The article investigates the reasons for this animosity and offers the researcher the pattern of the jupe-culotte, based on pattern-cutting manuals and period fashion magazines and in a museological institution, for artistic use and recreation.

[keywords] Jupe-culotte. Poiret. Diaghilev. Herminia Gonçalves.

Recebido em: 30-11-2020

Aprovado em: 09-02-2021

\footnotetext{
1 Livre-docente pela Escola de Comunicações e Artes da Universidade de São Paulo (ECA-USP). E-mail: faustoviana@uol.com.br. Lattes: http://lattes.cnpq.br/8433918896586792.

2 Livre-docente pela Escola de Artes, Ciências e Humanidades da Universidade de São Paulo (USP). E-mail: isabel.italiano@usp.br. Lattes: http://lattes.cnpq.br/4994816548757232.
} 


\section{Introdução}

O que teria causado tanta comoção na população paulistana naquele longínquo ano de 1911, quando chegou à cidade de São Paulo a jupe-culotte ou, como os jornais e revistas daqui chamariam, a saia-calção?

\section{FIGURAS 1 E 2 - HERMINIA GONÇALVES, PIONEIRA DO USO DA JUPE-CULOTTE EM SÃO PAULO}

(À ESQUERDA) E FOTO DE HERMINIA GONÇALVES EM ESTÚDIO (À DIREITA)

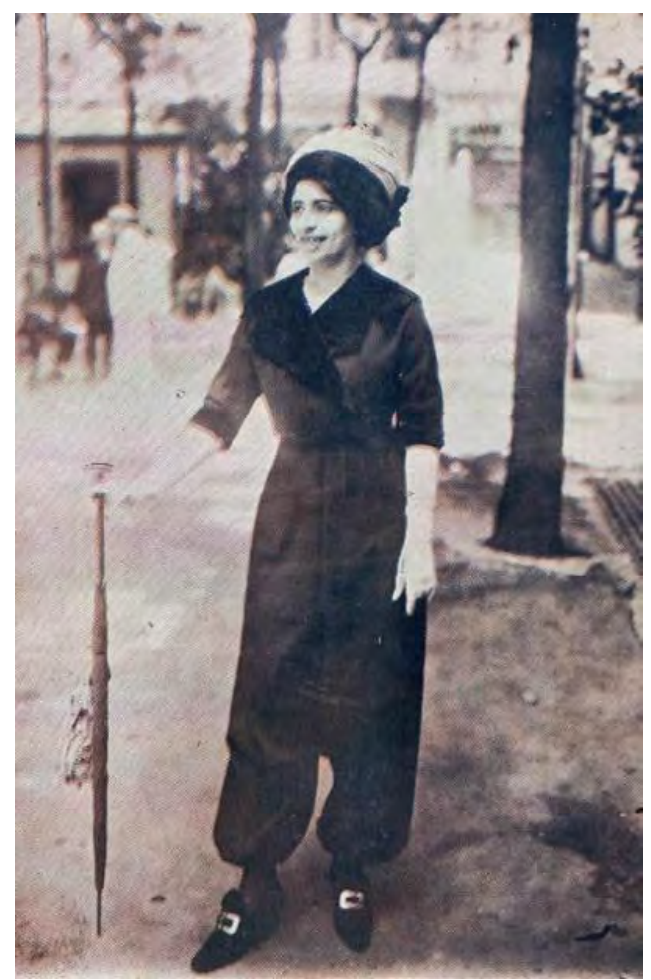

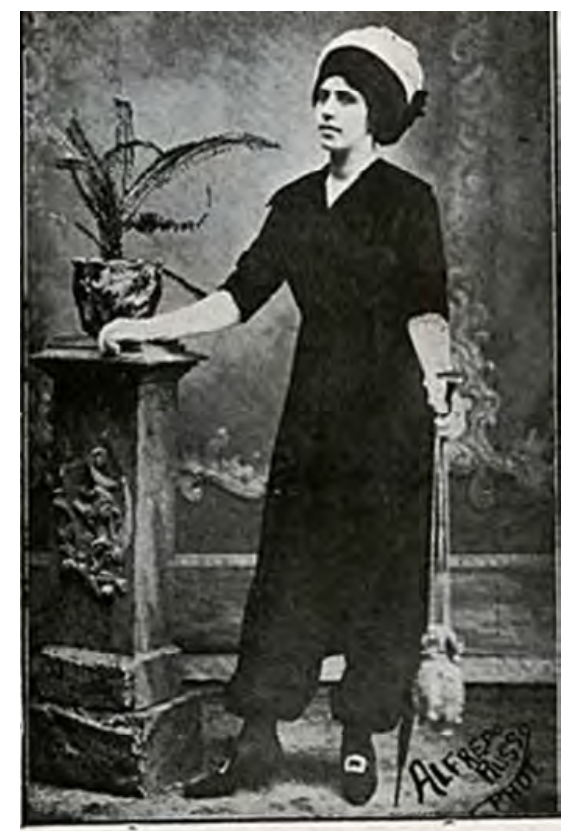

Mme. Herminia Gonçalves, proprietaria da cas de modas situada á r. S. João, 127-A, a juem coube a primasia no uso da Jupe-cullo te, em S. Paulo.

FONTE: Capa da revista Illustração Paulista, 23 de março de 1911 (figura 1).

Revista A Vida Moderna, 5 de abril de 1911 (figura 2).

Teria sido a declaração da médica e feminista Madeleine Pelletier publicada na Vogue ainda em 1911? Ela dizia:

Lutando pela liberdade do meu sexo, eu sou inimiga de tudo o que oprime [...] A liberdade de movimento conduz à liberdade de pensamento [...] Todas as mulheres com desejo verdadeiro de liberdade adotarão a nova moda com entusiasmo ${ }^{3}$. (BORRELLI-PERSSON, 2019)

\footnotetext{
${ }^{3}$ Tradução nossa para: "Struggling for the liberty of my sex, I am the enemy of all that oppresses [...] Liberty of movement is conducive to liberty of thought [...] All women really desirous of freedom will adopt the new fashion with enthusiasm". Disponível em: https://www.vogue.com/article/the-ups-and-downs-of-culottes-a-brief-history-from-paul-poiret-to-hedi-slimane. Acesso em: 18 jun. 2020.
} 
De fato, uma das principais preocupações era a masculinização da mulher ao adotar um traje que pertencia, tradicionalmente, ao guarda-roupa masculino - mas seriam os homens paulistanos tão inseguros a ponto de se deixarem abalar pelo mais novo modismo vindo de Paris? Como será visto, tudo indica que sim.

Garcia Redondo assinou um artigo na revista Illustração Paulista, de 23 de fevereiro de 1911, chamado Sobre o casamento, com o subtítulo Alguns conceitos ouvidos n'um five ó (sic) clock. Tratava-se de um relato pretensamente lúdico de um chá acontecido na casa de uma baronesa recém-viúva - ela, pelo período de luto, não poderia participar de um evento social e muito menos emitir opiniões -, o que já faz com que qualquer leitor contemporâneo levante a sobrancelha em assombro. Mas ela decide participar e diz que vai mesmo emitir opiniões, desde que tudo seja feito "sem alusões ferinas ou levemente sarcásticas”. Faziam parte da roda homens e mulheres, casados, viúvos e viúvas, celibatários e celibatárias, "sendo vedado a estes últimos emitir opiniões sobre o assunto, por falta de experiência. Foi um velho conselheiro quem estabeleceu a conversa com uma frase dita de maneira "cariciosa, quase suplicante", como descreveu Garcia Redondo. "O casamento é um bilhete de loteria", e depois complementou com um "que umas vezes está branco, outras têm prêmio" (REDONDO, 1911, p. 2).

Um espasmo de arrebatamento tomou conta do ambiente, mas um visconde idoso partiu em auxílio do colega, dizendo que o casamento era "uma necessidade, um verdadeiro freio à devassidão. Sem ele, a sociedade seria um caos, uma espécie de casa de comércio com dono ausente" (REDONDO, 1911, p. 2), provocando ampla discussão, quando um dos jovens perguntou então se o casamento não seria uma loucura. Os dois anciões haviam deixado a mensagem subliminar, mas clara: o casamento era a regra para manter as mulheres sob controle. Redondo escreve que

a roda feminina protestou com energia e a discussão generalizou-se. Veio à baila
o feminismo, a teoria de Lacour sobre a humanidade integrada na igual emulação
dos sexos reconciliados, fraternalmente unidos, mas dando-se à mulher direitos
iguais aos do homem. [...] Alguém pretendeu arriscar uma ideia sobre o amor
livre, única vereda para chegar à felicidade suprema, mas a voz foi abafada pela
baronesa, que exclamou:

- Precisamos de ordem, meus amigos. Temos sobre o tapete dois conceitos - o casamento é uma necessidade, o casamento é uma loucura - discutamos sobre eles. (REDONDO, 1911, p. 2)

Tudo termina quando um celibatário é instado a emitir uma opinião. Ele sem hesitar diz que "se um homem casa com uma mulher zarolha, coxa e sem dentes, mas que tem um dote de 300 contos, o casamento é uma necessidade; agora, quando casa com uma bela rapariga, sem defeito físico, mas sem vintém é... uma loucura" (REDONDO, 1911, p. 2).

0 preconceito contra a mulher fica latente logo nas primeiras linhas do artigo de Redondo, ainda que travestido de ironia fina, o que não é justificativa, nem para os tempos 
atuais, nem deve ter sido naquela época, pois coloca a mulher na condição de submissão, de enfeite do lar e responsável única e exclusivamente pelo sucesso ou pelo fracasso do casamento. Ao longo deste artigo, será possível perceber que a opinião masculina sobre a mulher, de forma amena ou não, é de absoluta superioridade sobre o belo sexo de então.

\section{A origem da saia-calção}

Paul Poiret (1879-1944), costureiro francês, havia lançado em 1911 uma pantalona inspirado em um harém, de um Oriente fantasioso, que lhe foi bafejado pelos Balés Russos de Serguei Diaghilev. 0 espetáculo que inspirou Poiret foi Schéhérazade, com figurinos de Léon Bakst (1866-1924), do qual é possível ver o traje da Sultana Azul (figura 3).

\section{FIGURAS 3 E 4 - 0 DESENHO DE LÉON BAKST PARA SULTANA AZUL, 1910 (À ESQUERDA) E DENISE E} PAUL POIRET NA FESTA AS MIL E DUAS NOITES, EM 24 DE JUNHO DE 1911 (À DIREITA)
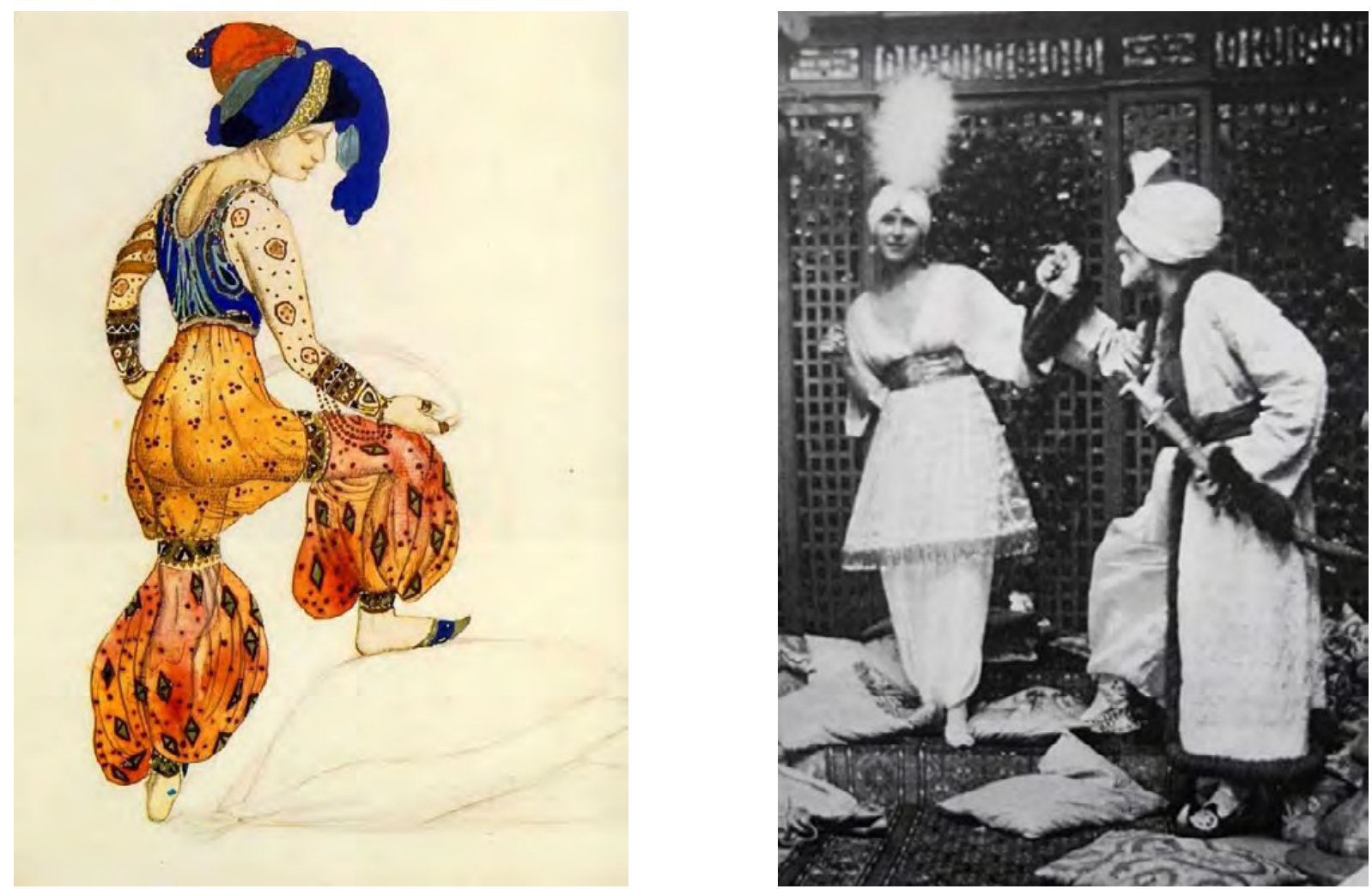

FONTE: KODA; BOLTON, 2007.

Poiret promove uma festa em sua casa para trezentos convidados, mas exige que todos estejam vestidos com o tema da festa: As mil e duas noites. Harold Koda e Andrew Bolton, curadores do The Metropolitan Museum, explicam que "as modas e a cenografia [da festa] refletiam um Oriente pantomímico, fantasmagórico e mítico” (KODA; BOLTON, 2007, p. 14), e a esposa de Poiret trajava uma calça fantasiosa de chiffon, como se pode ver na figura 4, muito menos reveladora das formas humanas do que o traje do balé. 
Não seria um equívoco afirmar, no entanto, que a calça já tinha feito sua tentativa de escapar do mundo da moda masculina antes, ainda no século XIX. James Laver (1899-1975), historiador da moda e curador do Victoria and Albert Museum, escreveu que "mesmo antes de a crinolina existir, havia rumores na América a respeito de um novo movimento para um traje racional para a mulher" (LAVER, 1989, p. 180). 0 movimento era produzido por Amelia Bloomer (1818-1894).

A admirável Mrs. Bloomer foi à Inglaterra em 1851 pregar suas ideias e tentar convencer as mulheres a adotar seu traje sensato e, certamente, feminino. Ele consistia em uma versão simplificada do corpete em voga e uma saia razoavelmente ampla bem abaixo dos joelhos. Sob a saia, entretanto, viam-se calças largas até o tornozelo, geralmente com um babado de renda na barra. Essa modesta tentativa de reformar os trajes femininos provocou uma explosão quase inacreditável de agitação, gracejos e censura. 0 que podemos chamar de complexo das calças veio à tona. As mulheres estavam empenhadas, ao que parecia, em "usar as calças", e o homem de meados do período vitoriano consideravam tal atitude um ataque ultrajante à sua posição privilegiada. (LAVER, 1989, p. 183)

Foi apenas em 1894 que, com a popularização das bicicletas, houve a necessidade de um traje bifurcado - ou seria impossível conduzir o veículo. Surgem assim as saias divididas e "os knickerbockers largos, também chamados bloomers" (LAVER, 1989, p. 208). Foram mais uma vez ridicularizados, mas as mulheres jovens ignoraram todas as críticas e continuaram a usá-los, o que também lançaria um novo olhar para a produção de roupas esportivas.

Apesar das origens distintas, tanto as calças da sultana árabe como a da sra. Bloomer eram... calças! Mas a de Poiret preferiu seguir o modelo da calça mística, de um Oriente sedutor que envolvia a Europa naquele período, enchendo a imaginação das mulheres.

\section{A chegada das jupes-culottes no Brasil}

No dia 15 de março de 1911, A Vida Moderna publicou um sério questionamento:

Em Paris, onde surgiu essa aberrante inovação, a assuada rompeu forte e estridente; em Lisboa, a grita foi enorme e solene; em Roma, suicida e brutal; no Rio de Janeiro, curiosa e grotesca. Não quererão as queridas senhoritas paulistas experimentar se a gente de S. Paulo sabe vaiar e rir? Experimentai, patrícias, que gostais de macaquear, porque precisamos rir. 0 riso é a melhor coisa da vida. (A VIDA MODERNA, ed. 85, v. 1, p. 8)

Na mesma edição, dizia que "as mulheres querem andar mais a gosto e à frescata [...] Mulher de calções. Soberbo! [...] Deus nos acuda!" (A VIDA MODERNA, edição 85, v. 1, p. 8). Todo o texto revela uma ameaça às mulheres que tentassem vestir as tais roupas modernas. 
Das duas principais revistas que consultamos para esta publicação, Illustração Paulista e A Vida Moderna, é curioso notar que, ao longo das edições do ano de 1911, há inúmeras reportagens nas quais a mulher era vítima de alguém: do marido, do amante ou dos dois. A violência contra ela acontecia constantemente.

A pioneira do uso da jupe-culotte em São Paulo foi Herminia Gonçalves, cujas imagens abrem este artigo (figuras 1 e 2). Herminia era, de acordo com A Vida Moderna, dona de uma casa de modas na Rua São João, 127-A, chamada Au paradis des Dames. Ela era casada com José Leonardo Gonçalves, secretário da empresa Polytheama (um teatro), e teria sido "a primeira a pôr de lado os tolos preconceitos com que se tem arguido de imprópria a nova vestimenta (ILLUSTRAÇÃO PAULISTA, 23 de março de 1911).

A matéria do jornal $O$ Estado de S. Paulo, de 20 de março de 1911 (figura 5), relata que o casal esteve no hipódromo um dia antes, portanto, em 19 de março, e que ela havia sido ovacionada pelos presentes pelo uso da jupe-culotte.

Pode ser que tenha havido controvérsia. No dia 23 de março de 1911, a Illustração Paulista publicou na capa a imagem da figura 1. Parece um bom sinal, mas no interior da revista, que não é numerado, veiculou a charge da figura 6, cuja legenda diz:

- Então, que tal me achas?

- Eu te acho divina. Mas nesse andar, minha flor, lá se vai a supremacia masculina por água abaixo... (ILLUSTRAÇÃO PAULISTA, 1911, s.p.)

\section{FIGURAS 5 E 6 - CAPA DE $O$ ESTADO DE S. PAULO, 20 DE MARÇO DE 1911 (À ESQUERDA) E CHARGE DA REVISTA ILLUSTRAÇÃO PAULISTA, 23 DE MARÇO DE 1911 (À DIREITA)}
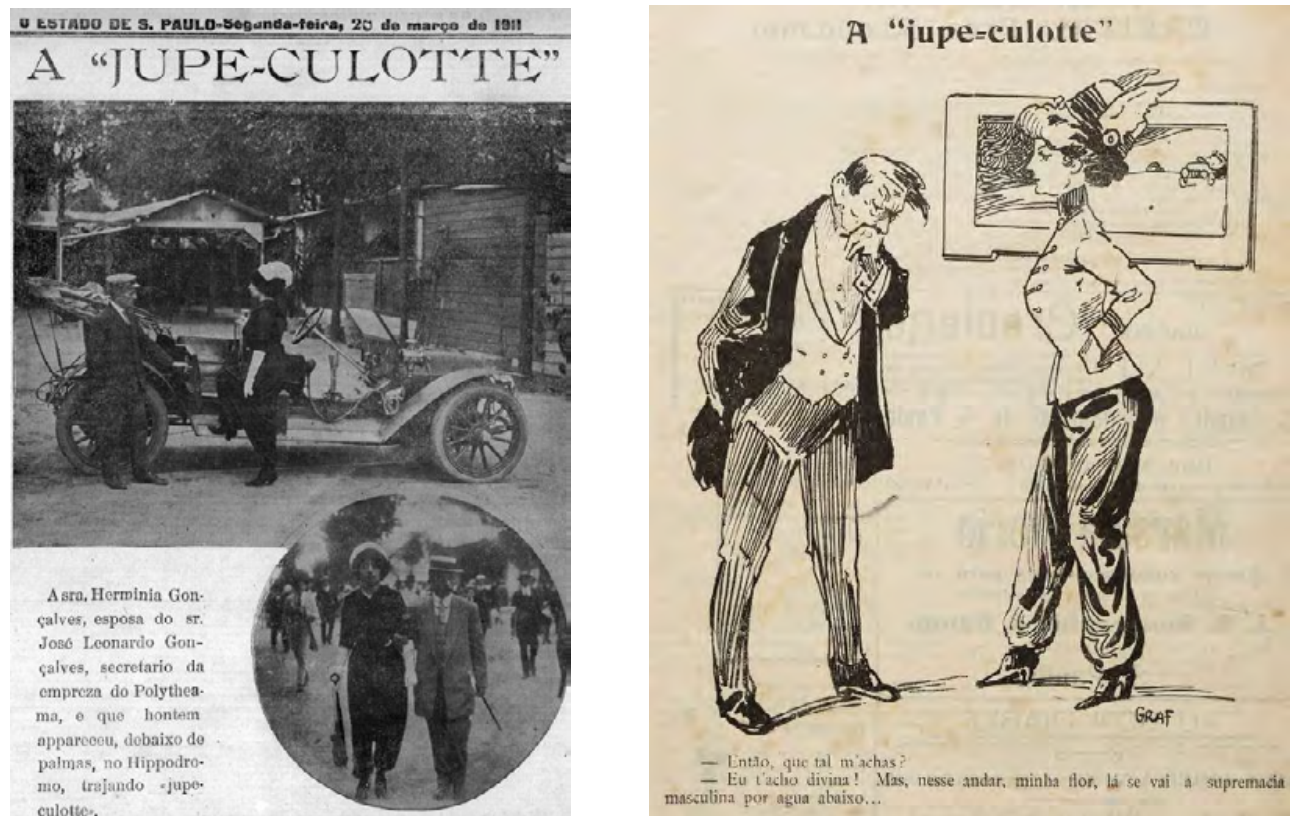

FONTE: Acervo O Estado de S. Paulo. Disponível em: https://acervo.estadao.com.br/pagina/\#!/1911032011783-nac-0003-999-3-not. Acesso em: 3 nov. 2020 (figura 5). Biblioteca Nacional. Disponível em: http:// memoria.bn.br/DocReader/DocReader.aspx?bib=186848\&pagfis=355. Acesso em: 9 mar. 2021 (figura 6). 
Mais do que isso, na mesma edição, lançaram um concurso "entre suas gentis leitoras para saber o que pensam sobre a adoção da jupe-culotte” (ILLUSTRAÇÃO PAULISTA, 23 de março de 1911, s.p). A leitora deveria preencher o questionário (figura 7) e entregar na redação da revista.

\section{FIGURA 7 - 0 “QUESTIONÁRIO” PUBLICADO PELA ILLUSTRAÇÃO PAULISTA}

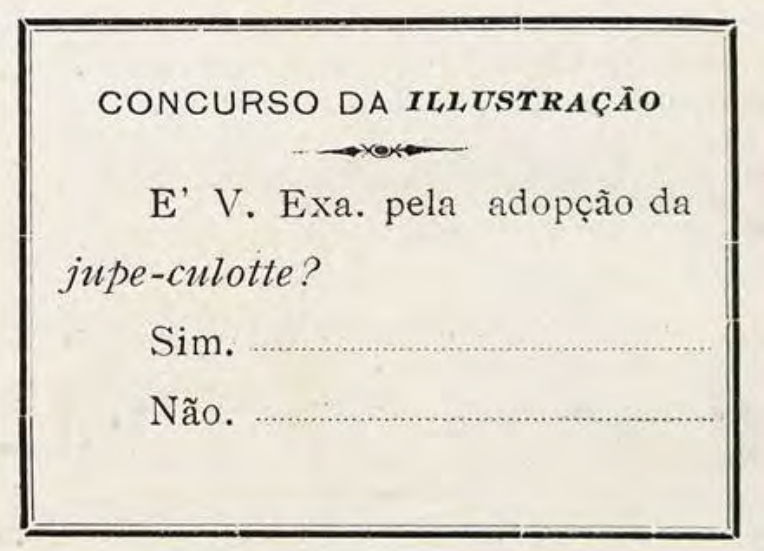

FONTE: Biblioteca Nacional. Disponível em: http://memoria.bn.br/DocReader/DocReader. aspx?bib=186848\&pagfis=355. Acesso em: 9 mar. 2021.

Demonstrando a neutralidade da revista, nas páginas seguintes, foi publicado o texto da coluna Moda, assinada por Mademoiselle Paquin (pseudônimo da colunista, não se refere à estilista Jeanne Paquin (1869-1936)). Dizia a Paquin dos trópicos, em evidente contradição:

[...] o leitmotiv de hoje será a já famigerada jupe-culotte. A insensata relutância que lhe tem sido oposta não tem obedecido a um seguro critério de crítica; guerreiam-na quand même, por vãos motivos, cada qual mais excêntrico, desconexo e refutável. [...] Haverá razão plausível para que seja ela dotada? Talvez. [...] Não poderão chamar de imoral a jupe-culotte, quando mal delineia ela as formas de sua portadora, dando-lhe a mais completa liberdade de ação e movimento. (ILLUSTRAÇÃO PAULISTA, 1911, n. 12, p. 15)

Nesse trecho, havia alguma contradição no texto da colunista quando ela diz que é famigerada, mas que não há nada de imoral no seu uso! Fica um tanto quanto incompreensível a postura da autora, conclamando as leitoras a concordarem que "o nosso sexo é que não devia tentar assenhorar-se de atributos do sexo oposto: vencermos, usarmos a jupe-culotte, será uma vitória de Pyrrho ${ }^{4}$, que podemos ter opiniões, mas certeza e conhecimento são impossíveis), perderemos mesmo com ganho de causa" (ILLUSTRAÇÃO PAULISTA, 1911, n. 12, p. 15).

\footnotetext{
${ }^{4}$ Pirro foi um filósofo grego que afirmou, entre outras citações, que podemos ter opiniões, mas certeza e conhecimento são impossíveis.
} 
Não se pode aceitar inteiramente aquilo que se lê, e a tal colunista Mademoiselle Paquin pode ter entregue a sua verdadeira identidade - masculina - ao descrever que a mulher não deve desprezar suas armas de combate: "as rendas, fitas, fanfreluches, bazins e outros tantos nonadas", ou seja, tudo aquilo que parecia fraqueza, mas, na verdade, era sua força, devendo a mulher entregar-se então "à discrição, ao inimigo vencido" - o homem (ILLUSTRAÇÃO PAULISTA, 1911, n. 12, p. 15). Quanto à jupe-culotte, a colunista dá a sentença final: "A jupe-culotte, já o dissemos, nada tem de imoral, falta-lhe a graça do vestido colante; não a guerreamos; que a usem, porém, não aconselharemos" (ILLUSTRAÇÃO PAULISTA, 1911, n. 12, p. 15). Tornando ainda mais difícil o ponto ao qual desejava chegar, Mademoiselle Paquin publica uma excelente imagem (figura 8) em que aparecem diversos modelos de jupe-culotte.

FIGURA 8 - OS DIVERSOS MODELOS DE JUPE-CULOTTE PUBLICADOS NA ILLUSTRAÇÃO PAULISTA

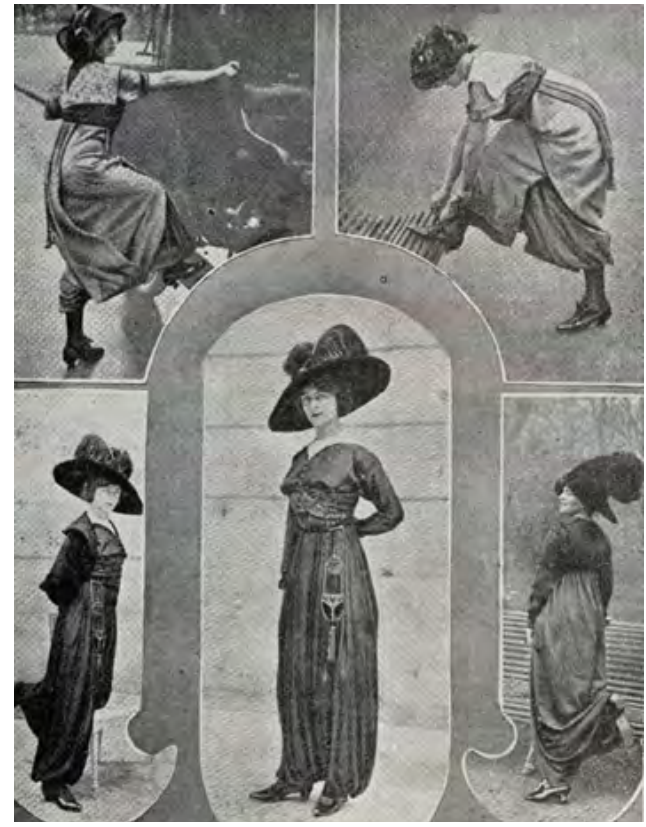

FONTE: Biblioteca Nacional. Disponível em: http://memoria.bn.br/DocReader/DocReader. aspx?bib=186848\&pagfis=360. Acesso em: 10 mar. 2021.

Eis que em 30 de março, a revista vem à carga com charges absolutamente contra a jupe-culotte. E textos dizendo que receberam um telegrama de Curitiba avisando que, quando as jupes-culottes chegassem lá, um grupo de rapazes pretendia sair às ruas com saias. A publicação, na sua total neutralidade, diz:

A ideia é genial e, como protesto à audaciosa tentativa que ora fazem as mulheres para envergar o culote, é um pouco mais aceitável do que as estúpidas e grosseiras vaias com que os ociosos da Avenida Central e da rua do Ouvidor agrediram as primeiras damas que vestiram a saia calção na Capital da República. (ILLUSTRAÇÃO PAULISTA, 1911, n. 13, p. 11) 
FIGURAS 9, 10 E 11 - CHARGE NA QUAL SE LÊ: "A JUPE-CULOTTE. FUTURA VINGANÇA DE UM MARMANJO" (À ESQUERDA); CHARGE NA QUAL SE LÊ: "VINGANÇA - ESTÁ TUDO ACABADO ENTRE NÓS. - NÃO FAZ MAL, INGRATA. A JUPE-CULOTTE QUE A PERSIGA!...” (AO CENTRO); E CHARGE NA QUAL SE LÊ: "UMA OPINIÃO - QUE TAL ACHAS A JUPE-CULOTTE? SMART, CHIC, ELEGANTE, DERNIER CRI?... - MUITO

CHIC E EXTRAORDINARIAMENTE DERNIER CRI... PARA AS MULHERES DOS OUTROS." (À DIREITA)
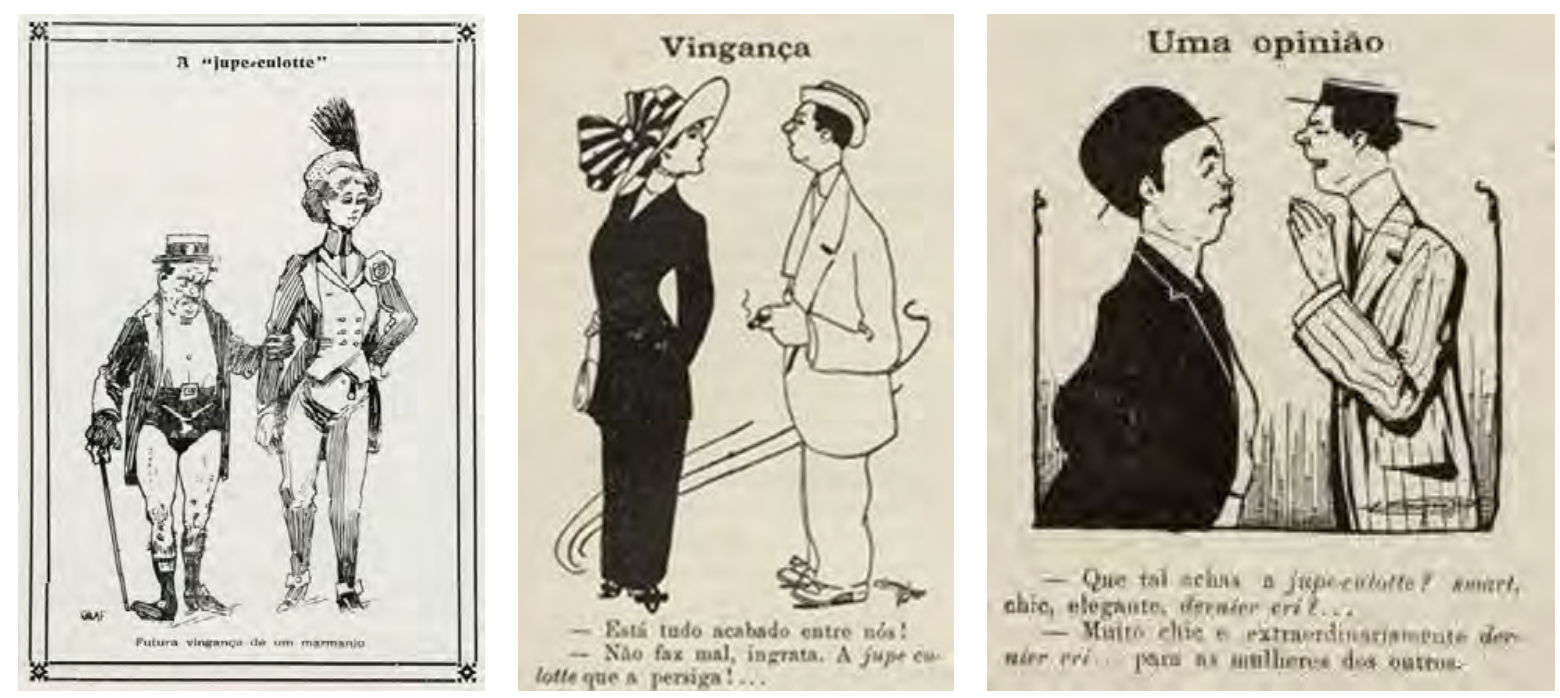

FONTE: : Illustração Paulista, 23 de março de 1911. Disponível em: http://memoria.bn.br/ DocReader/DocReader.aspx?bib=186848\&pagfis=345. Acesso em: 10 mar. 2021 (figura 9). Illustração

Paulista, 30 de março de 1911. Disponível em: http://memoria.bn.br/DocReader/DocReader. aspx?bib=186848\&pagfis=360. Acesso em: 10 mar. 2021 (figuras 10 e 11).

Quanto ao concurso, a votação foi - é de pasmar - de total reprovação. Não houve um voto favorável ao uso da jupe-culotte. Diz a intrigada colunista: "Foram muitos os votos que recebemos, unânimes todos em reprovar a nova moda. Qual a razão? [...] Talvez o receio de palmas em plena avenida [...]". Ela se vê, diante de tanta oposição, obrigada a encerrar o concurso, "que perdeu todo o interesse". Mas profetiza, fechando com a chave da contradição, o que havia escrito até então: "Queremos crer, porém, que não se passará um mês, e a jupe-culotte será a moda dominante em São Paulo, e exalçada por estas mesmas que ora se manifestam contra ela..." (ILLUSTRAÇÃO PAULISTA, 1911, n. 13, p. 13).

\section{A modelagem e a confecção da jupe-culotte}

A pesquisa para a modelagem e a confecção da jupe-culotte foi feita a partir de manuais de modelagem e revistas de moda da época. Após busca extensiva, não foi possível encontrar, nesse material, instruções ou indicações para a sua confecção. Fácil entender: uma peça do vestuário feminino que causou tanta polêmica não faria parte dos métodos de ensino de modelagem e costura, seja nos usados em cursos de costura da época ou nos elaborados para quem aprendia e costurava em casa.

No livro de modelagem de trajes femininos de J. P. Thornton (1911), foram encontrados apenas os moldes de saias-calças para montaria ou ciclismo, como as que aparecem na figura 12. 
FIGURA 12 - MODELAGENS DE SAIAS-CALÇAS PARA MONTARIA, CONFORME LIVRO DE MODELAGEM DE THORNTON, 1911
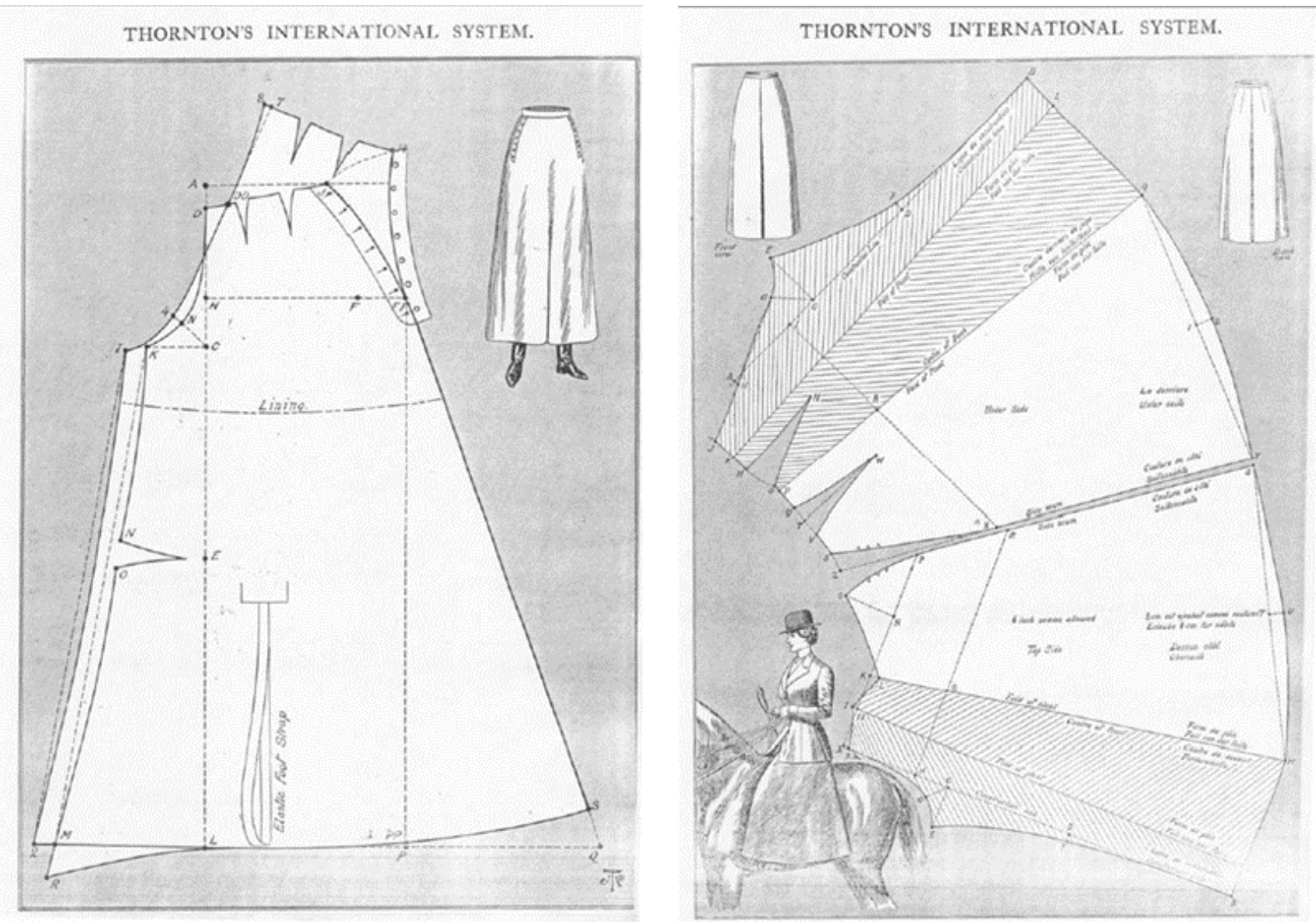

FONTE: THORNTON (1911, p. 340 e 343).

Por fim, um tipo de harem pants (calça no estilo árabe), parte do acervo do Los Angeles County Museum of Art (LACMA), foi encontrado durante as pesquisas e apresentava uma minuciosa documentação, produzida pela equipe do museu, incluindo fotos, detalhes dos acabamentos e a modelagem. A documentação da peça é parte de um projeto desenvolvido pelo LACMA chamado Undertaking the Making: LACMA Costume and Textiles Pattern Project ${ }^{5}$ sendo, de acordo com o site da instituição, um projeto em que se produzem recursos on-line de livre acesso com modelagens de trajes históricos da coleção permanente.

Os moldes são acompanhados por uma descrição com contexto histórico e observações feitas sobre a peça, além de incluir imagens detalhadas e instruções básicas para a sua construção. 0 site ainda informa que "os moldes foram elaborados a partir de um processo de engenharia reversa no qual um traje tridimensional é desconstruído para sua forma plana bidimensional original"6 (UNDERTAKING THE MAKING, s.d.),

\footnotetext{
Disponível em: https://www. lacma.org/patternproject. Acesso em: 16 ago. 2020.

6 Tradução nossa para: "The patterns were drawn in a process of reverse engineering where a three-dimensional costume object was 'de-constructed' back to its original two-dimensional flat form".
} 
A peça é uma jupe-culotte, datada de c.1913, feita em tule e cetim de seda, com passamanaria em linha metálica (número no acervo 54.97.17a-b), muito parecida com aquela mostrada na figura 8 (foto ao centro, em destaque).

De acordo com a descrição do museu, o item do acervo é uma lounging pajamas, mostrada na figura 13.

FIGURA 13 - SAIA-CALÇÃO, DATADA DE C.1913, PEÇA DO ACERVO DO LOS ANGELES COUNTY MUSEUM OF ART (54.97.17A-B)

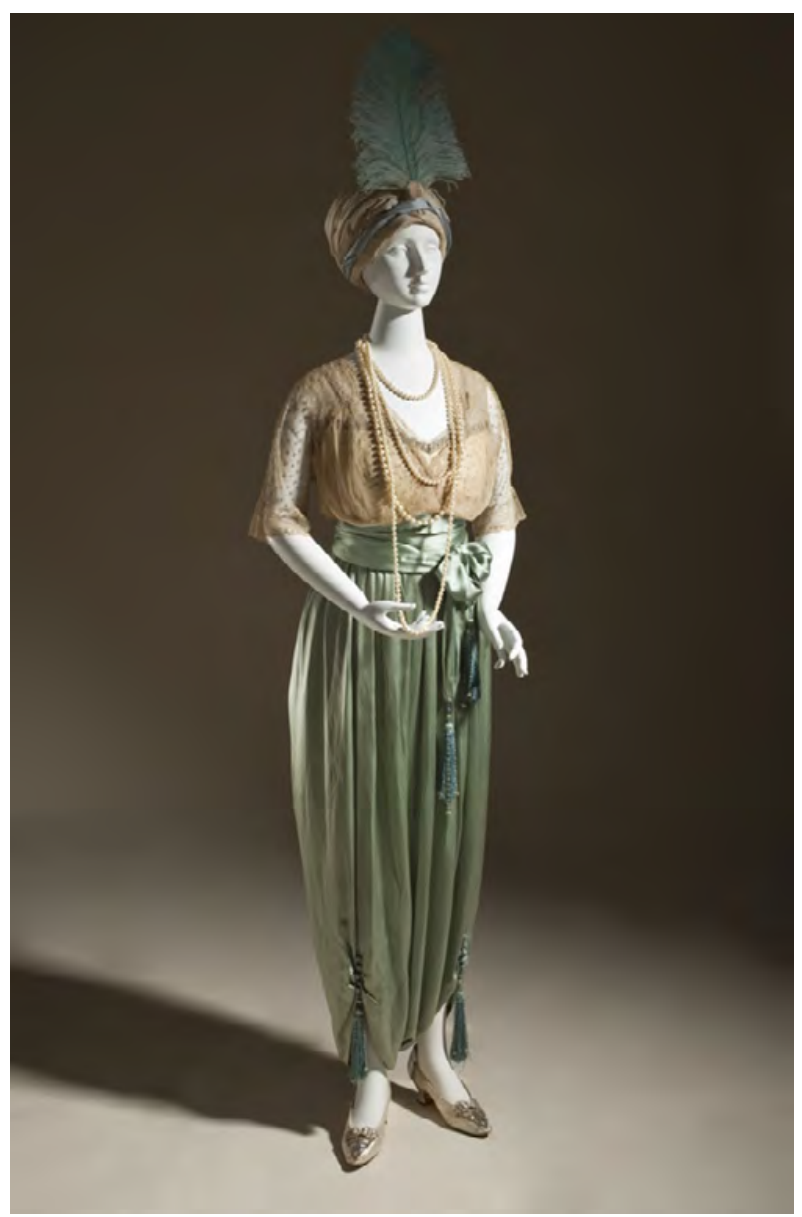

FONTE: Los Angeles County Museum of Art. Disponível em: https://collections.lacma.org/node/230873. Acesso em: 10 ago. 2020.

Feita com uma única parte de tecido, tem a cintura alta franzida, com acabamento em ponto smocking, ou casa de abelha, para garantir o ajuste. A linha da cintura é bem alta, praticamente sob o busto, e é presa a um corpinho em renda. Possui costuras laterais deslocadas para a frente (isso é obtido pela diferença de largura do tecido na parte da frente e das costas) e pequenas aberturas para a passagem dos pés, para criar uma "harem pants estilizada”, de acordo com a documentação do LACMA (WOMAN'S LOUNGING PAJAMAS, s.d.). Nas costuras laterais, bem próximo das aberturas para os pés, são feitas duas pequenas pregas, 
e cinco botões de cada lado ornamentam a abertura, com um pingente de seda para dar acabamento. Uma longa faixa, do mesmo tecido da saia-calção, é amarrada na cintura sobre o franzido. A figura 14 mostra o detalhe do acabamento na abertura da saia-calção, conforme o documento descritivo da peça, elaborado pelo LACMA.

FIGURA 14 - DETALHE DO ACABAMENTO NA ABERTURA DA SAIA-CALÇÃO, PEÇA DO ACERVO DO LACMA

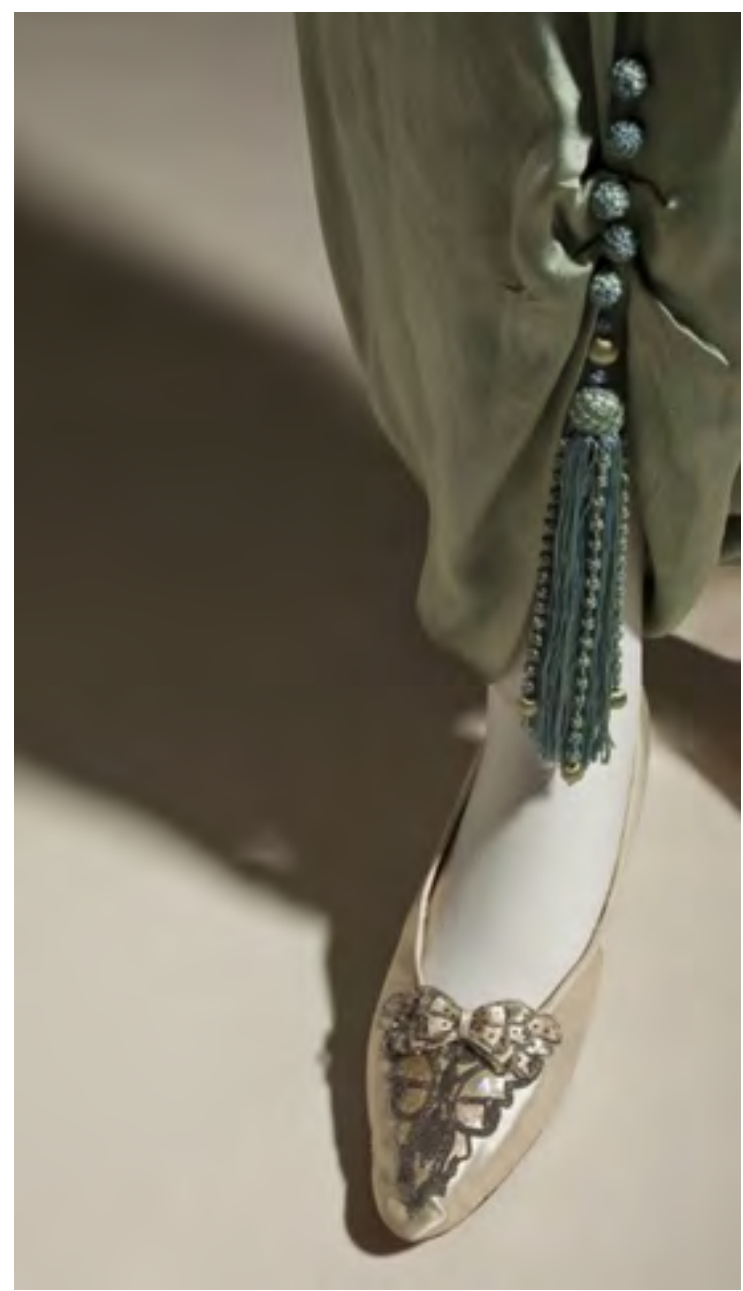

FONTE: Los Angeles County Museum of Art. Disponível em: https://collections.lacma.org/node/230873.

Acesso em: 10 ago. 2020.

Com o objetivo de validar a modelagem e o processo de confecção, foi desenvolvido um protótipo da peça, utilizando tecido cetim não muito encorpado, para melhor caimento, na cor nude. Os moldes foram reproduzidos exatamente como aqueles apresentados pelo documento do LACMA, com as mesmas dimensões e detalhes (figura 15). No entanto, o franzido da cintura foi ajustado de modo a servir para uma modelo específica. Cabe ressaltar que foi escolhida uma modelo alta (1,74 m de altura), para que a saia-calção ficasse com comprimento adequado. Para recriar a peça, deve-se ajustar o comprimento. 
FIGURA 15 - MOLDES DA SAIA-CALÇÃO ELABORADOS PELA EQUIPE DO LACMA.

À ESQUERDA, METADE DO MOLDE DA FAIXA DA CINTURA E, À DIREITA, 0 MOLDE DA SAIA-CALÇÃO. OS MOLDES FORAM DESENHADOS SOBRE UMA GRADE

QUADRICULADA DE 1 POLEGADA E NÃO INCLUEM MARGEM DE COSTURA

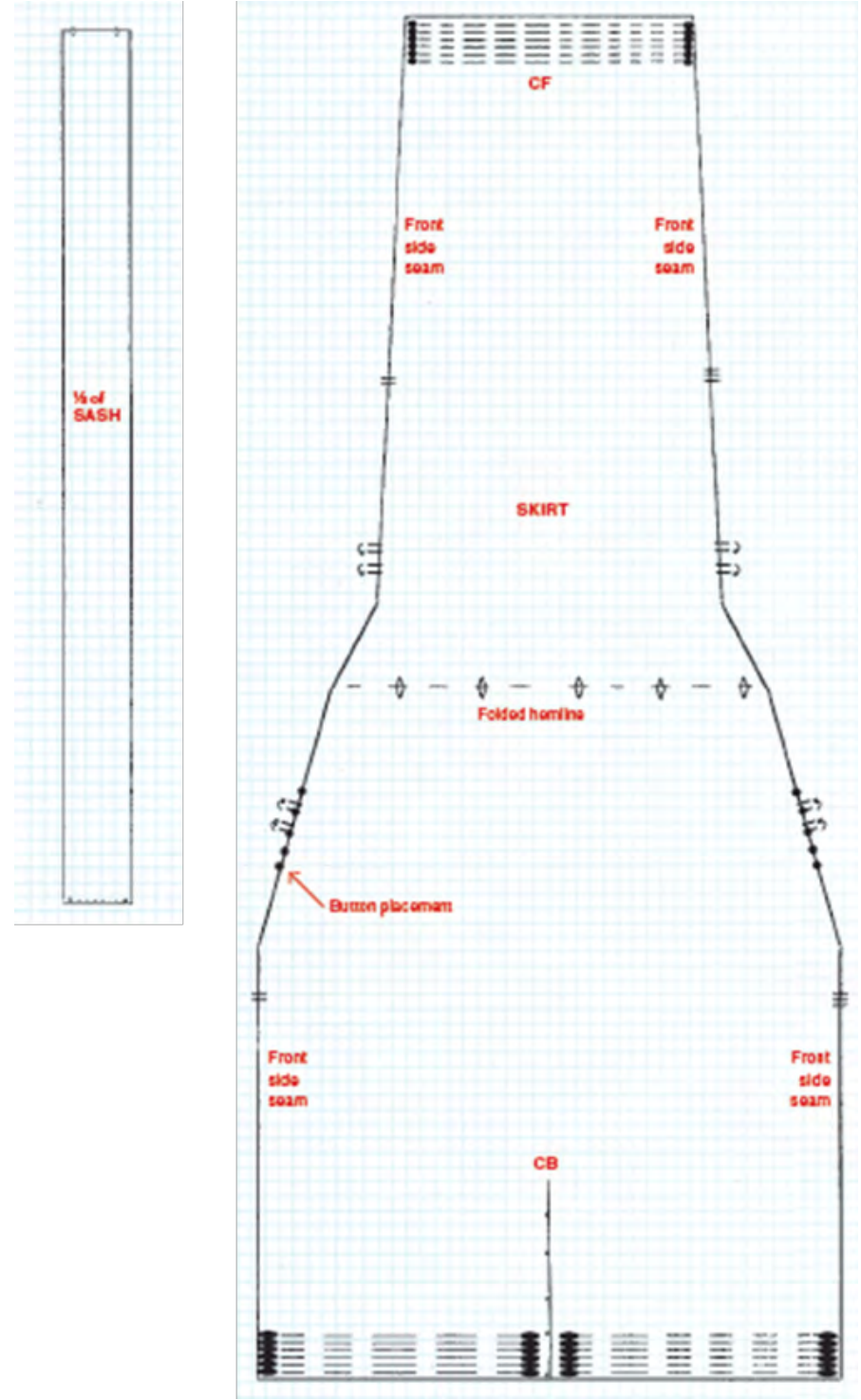

FONTE: Woman's Lounging Pajamas (s.d.).

A faixa é cortada em uma tira de 3 metros de comprimento por 12 centímetros de largura, aproximadamente, e costurada (dobrada) ao longo de seu comprimento. As pontas são franzidas e recebem acabamento com um pingente, suspenso por um cordão de seda de 5 centímetros.

A construção da saia-calção, propriamente dita, é relativamente simples, pois requer apenas a união das costuras laterais e o franzido da cintura. 0 acabamento, feito à mão em grande parte da peça, é o mais trabalhoso. 
A união das costuras laterais do protótipo foi feita por costura francesa. No descritivo do LACMA não há menção ao tipo de costura usado na peça original, no entanto, é bem provável que a francesa tenha sido o tipo de costura usado, já que sua utilização era bastante comum para tecidos finos, da mesma forma que atualmente. A costura francesa é descrita no livro publicado pela Butterick em 1911, obra bastante completa no que se refere às técnicas de costura e modelagem do período. A busca por uma publicação da época, que mostre a confecção de determinado tipo de costura (ou bordado), é importante para comprovar que a técnica existia e era utilizada, para que, sempre que possível, se lance mão de um método do período analisado. A figura 16 traz parte das instruções para a elaboração da costura francesa (french seam). A técnica é exatamente a que se usa hoje, porém, como já mencionado, é relevante mostrar sua execução, conforme manuais do período estudado.

FIGURA 16 - COSTURA FRANCESA, CONFORME INSTRUÇÕES NA PUBLICAÇÃO DA BUTTERICK, DE 1911

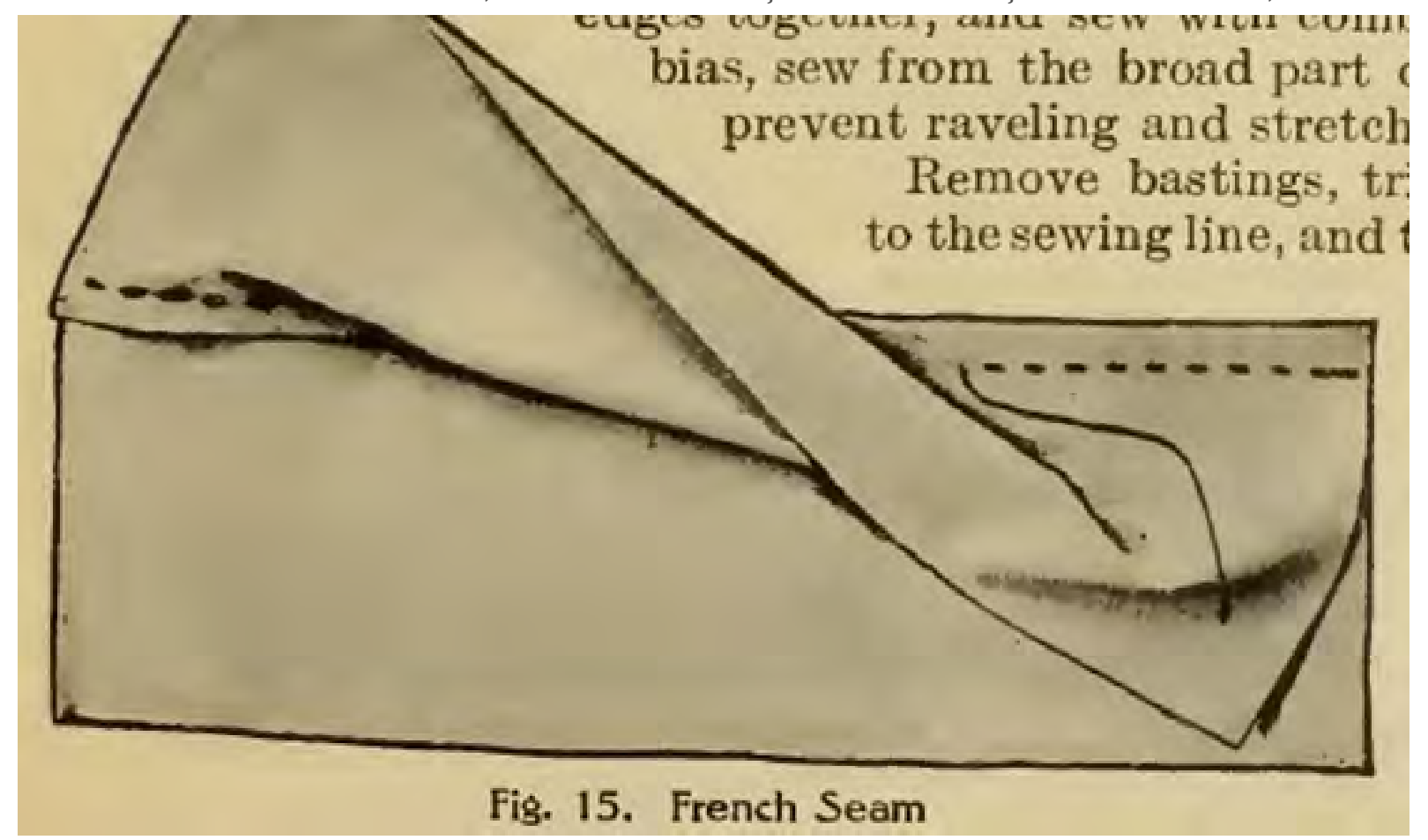

FONTE: BUTTERICK (1911, p. 5).

Para caracterizar o franzido da cintura, preso por pontos smock, partiu-se das informações e do diagrama disponível no documento descritivo da peça (WOMAN'S LOUNGING PAJAMAS, s.d.). Esse diagrama é mostrado na figura 17. 
FIGURA 17 - FRANZIDO NA CINTURA DA SAIA-CALÇÃO, PEÇA DO ACERVO DO LOS ANGELES COUNTY MUSEUM OF ARTS (VISÃO COM A BLUSA E DETALHE AMPLIADO)

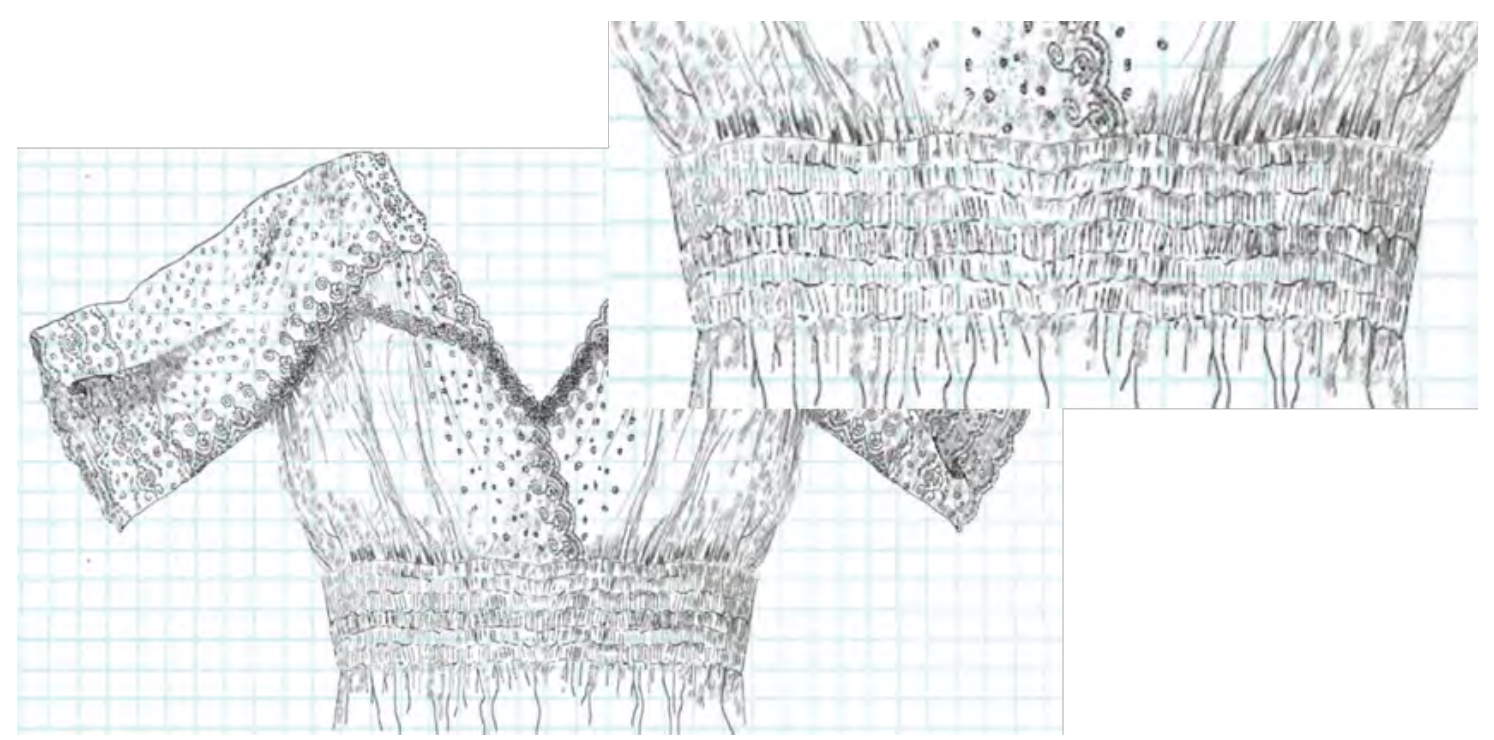

FONTE: Woman's Lounging Pajamas (s.d.).

Aparentemente, pela análise visual do diagrama, o trabalho é feito com pontos haste (também chamados cordonê), que são pontos smock simples, em seis linhas retas horizontais que prendem o franzido e não há um bordado muito elaborado. Para que a confecção do ponto smock fosse feita conforme uma técnica do período, foram utilizadas as instruções do livro publicado pela Butterick (1911). Nas páginas 27 e 28, a publicação ensina como preparar o material, por meio de marcações de pontos espaçados em intervalos regulares, formando quadrados perfeitos, além de incluir instruções para o franzido e para os vários pontos de bordado, de modo a formar o acabamento (figura 18).

\section{FIGURA 18 - PREPARAÇÃO PARA O PONTO SMOCK, CONFORME INSTRUÇÕES DA PUBLICAÇÃO DA BUTTERICK, DE 1911. MARCAÇÃO DOS PONTOS E COSTURA DO FRANZIDO}

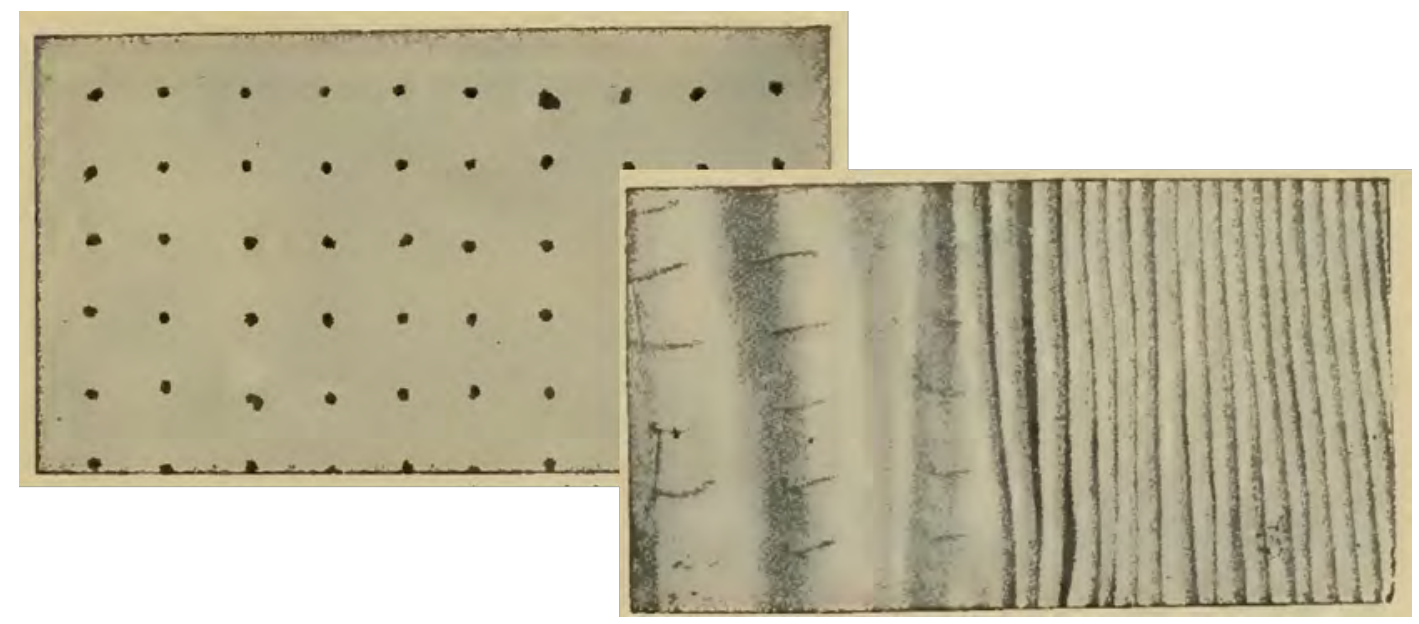

FONTE: BUTTERICK (1911, p. 27) 
O ponto smock utilizado como bordado na saia-calção é chamado, na publicação da Butterick, de outline stitch (figura 19).

\section{FIGURA 19 - PONTO SMOCK (OUTLINE STITCH), CONFORME INSTRUÇÕES DA PUBLICAÇÃO DA} BUTTERICK, DE 1911

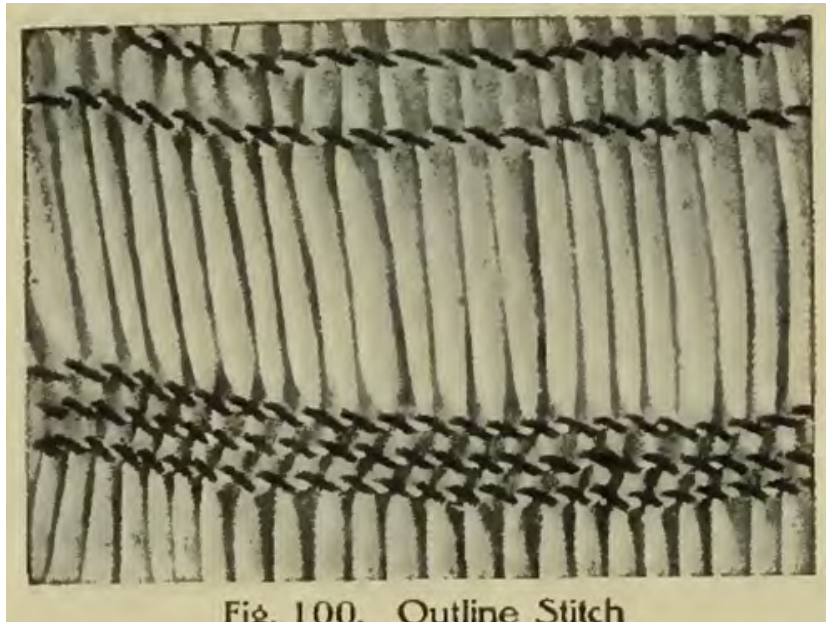

Fis. 100. Outline Stitch

FONTE: BUTTERICK (1911, p. 28).

Por questões práticas, para melhor visualização das linhas a serem franzidas e bordadas, em vez dos pontos para marcação da costura, sugeridos por Butterick (1911, p. 27), optou-se por quadricular a região que seria franzida, o que não afetou o processo, nem o resultado final. 0 quadriculado foi feito com seis linhas horizontais e várias verticais, formando quadrados de 1,5 cm de lado. As intersecções das linhas correspondem aos pontos de marcação sugeridos por Butterick (1911, p. 27). Um detalhe dessa marcação é mostrado na figura 20.

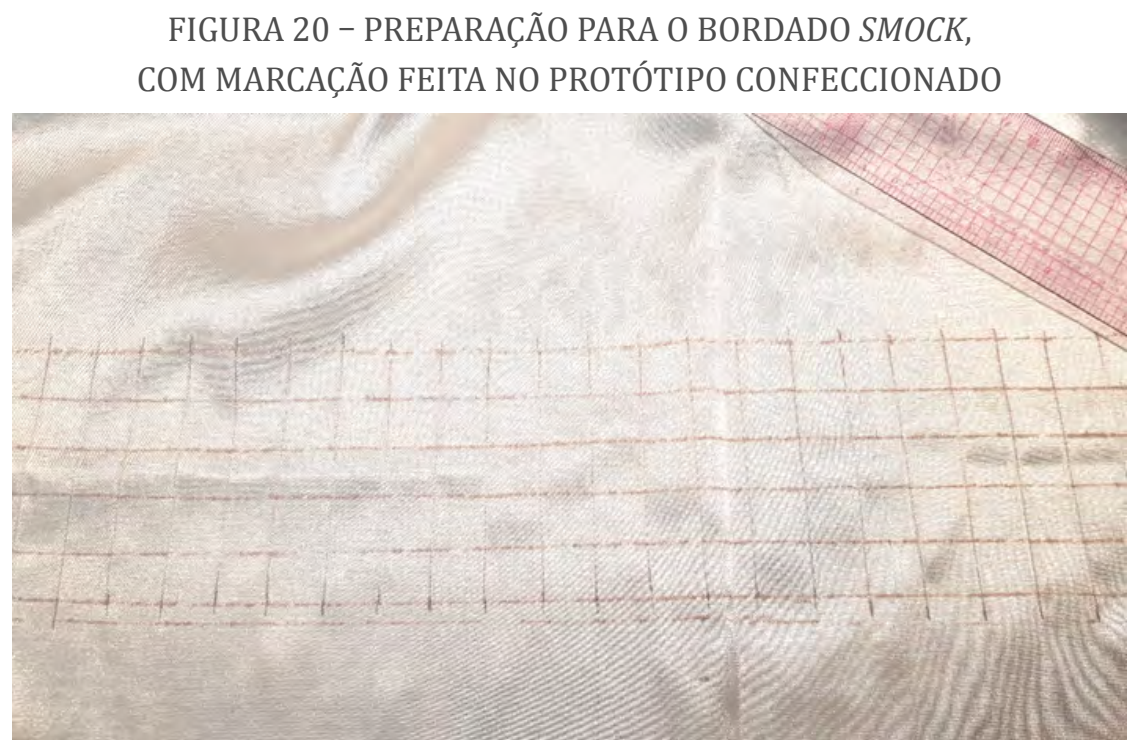

FONTE: Acervo do Núcleo de Traje de Cena, Indumentária e Tecnologia (USP). Foto: Isabel C. Italiano, 2020. 
Como o tecido usado no protótipo tem espessura fina, optou-se por fazer o franzido com tecido duplo, acrescido como se fosse margem de costura $(10 \mathrm{~cm})$ e dobrado na borda da linha da cintura, o que conferiu mais firmeza aos pontos do bordado.

Porém, o franzido, a partir do quadriculado de $1,5 \mathrm{~cm}$, não ficou adequado para o bordado em ponto smock e, assim, foi necessário refazê-lo, dessa vez utilizando marcação adicional e dividindo todos os quadrados de $1,5 \mathrm{~cm}$ ao meio, no sentido da altura. Isto resultou em um franzido mais volumoso, permitindo que o bordado ficasse mais parecido com o diagrama do LACMA, como mostra a figura 21.

FIGURA 21 - FRANZIDO E BORDADO, EM PONTO SMOCK, FEITO NA LINHA DA CINTURA ALTA NO PROTÓTIPO DA SAIA-CALÇÃO

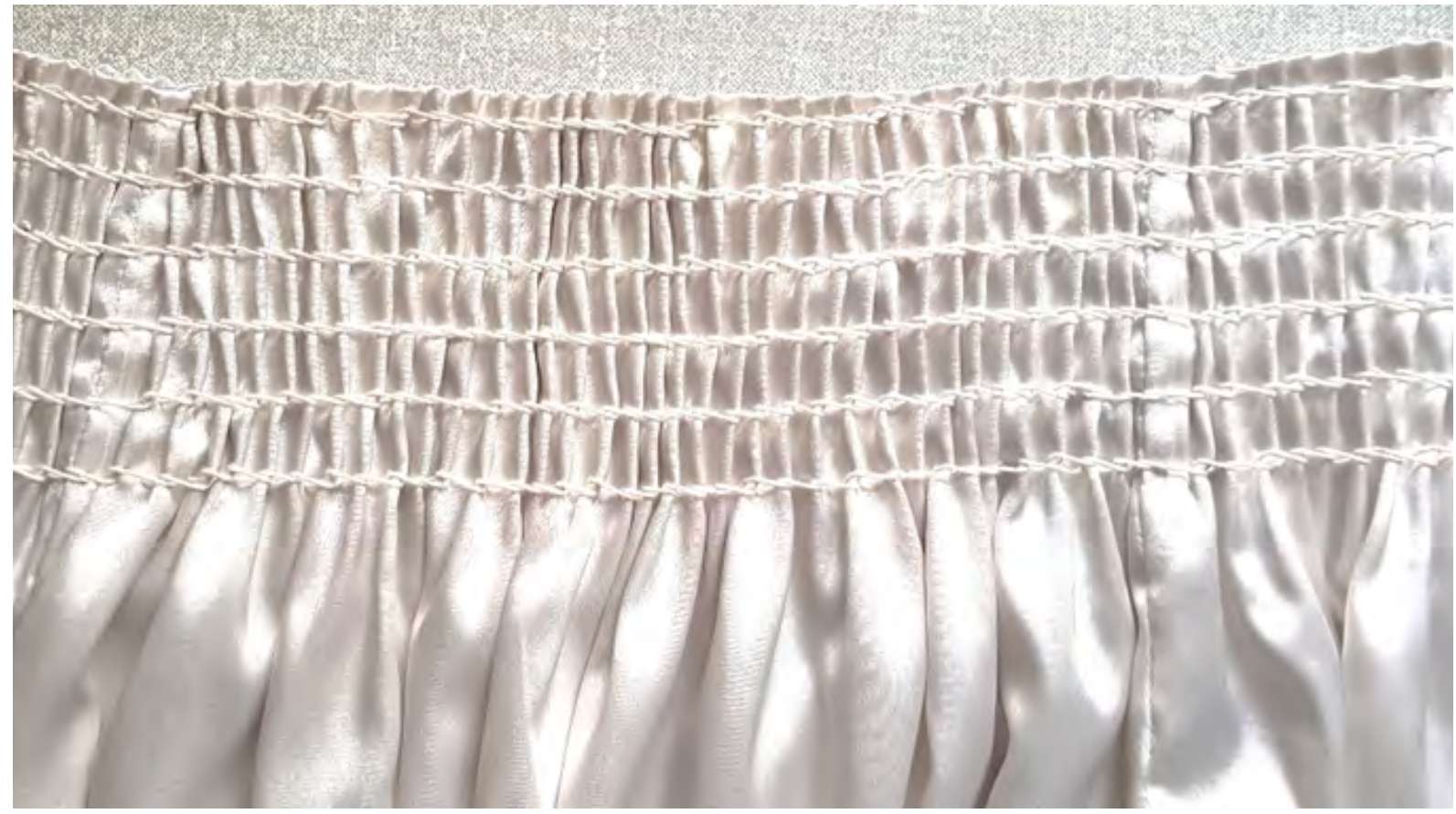

FONTE: Acervo do Núcleo de Traje de Cena, Indumentária e Tecnologia (USP). Foto: Isabel C. Italiano, 2020.

O descritivo do museu mostra, no diagrama de modelagem, que existe uma abertura traseira, no centro das costas, de, aproximadamente, $35 \mathrm{~cm}$ (medida tomada a partir da linha da cintura) e que o acabamento é feito por meio de uma carcela e cinco pares de colchetes. Da mesma forma que para as técnicas anteriores, buscou-se modos de fazer do período que mostrassem a elaboração das carcelas. 0 livro publicado por Butterick (1911) também revela essa técnica (figura 22). 
FIGURA 22 - CONFECÇÃO DA CARCELA INTEIRIÇA, CONFORME INSTRUÇÕES NA

PUBLICAÇÃO DA BUTTERICK, DE 1911. EM (A), A CARCELA CORTADA E VINCADA

(FIG. 116) E A CARCELA JÁ COSTURADA À ABERTURA (FIG. 117). EM (B), A CARCELA

JÁ DOBRADA NA POSIÇÃO CORRETA E, EM (C), A CARCELA FINALIZADA

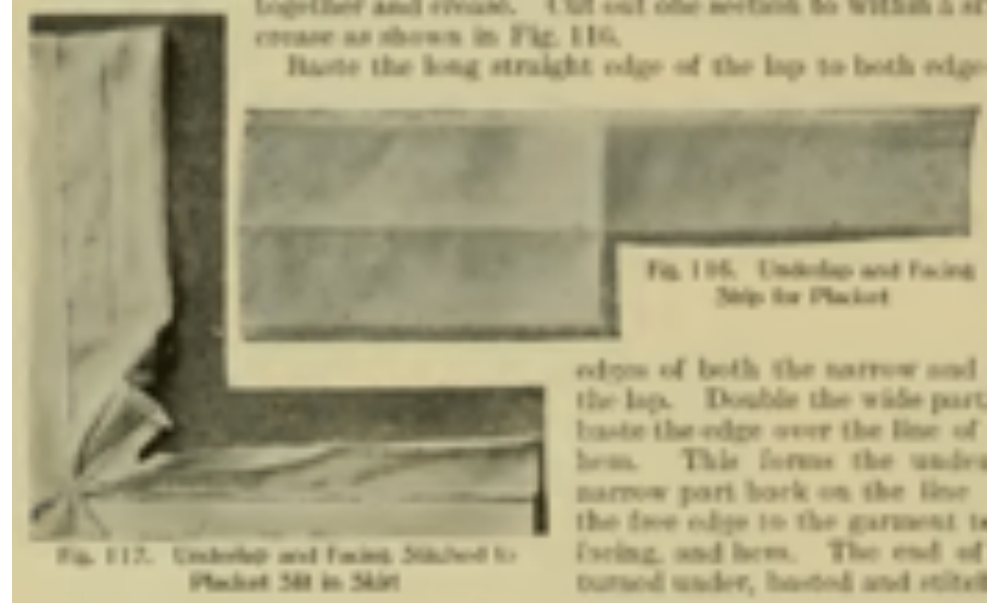

(A)

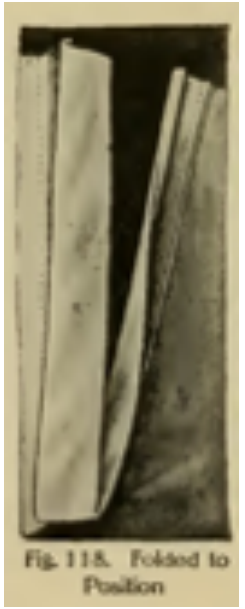

(B)

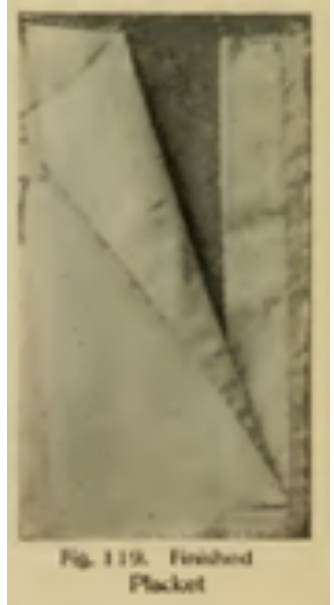

(C)

FONTE: BUTTERICK (1911, p. 32).

Para o protótipo foi feita uma carcela inteira (como mostrado na figura 22) e os colchetes foram colocados conforme a figura 23.

FIGURA 23 - COLOCAÇÃO DE COLCHETES EM CARCELA, CONFORME INSTRUÇÕES NA PUBLICAÇÃO DA BUTTERICK, DE 1911

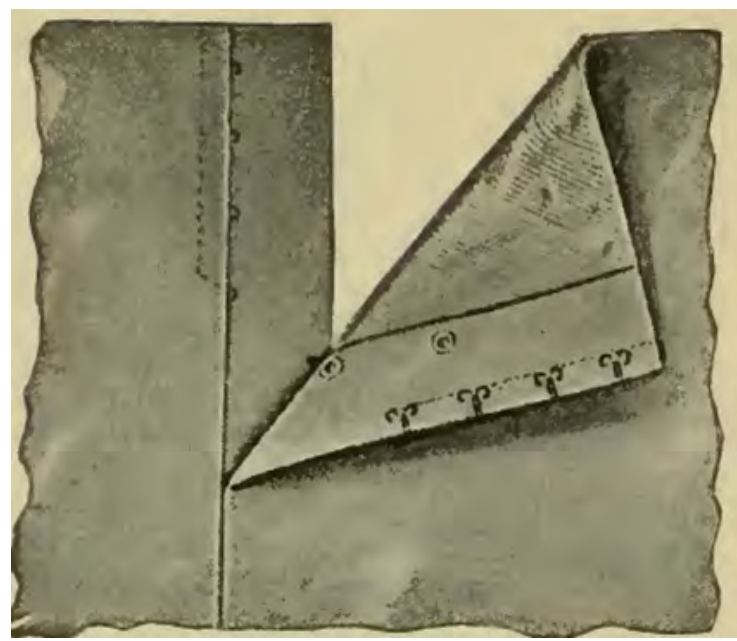

FONTE: BUTTERICK (1911, p. 34).

A escolha pela carcela inteira deve-se ao fato de a saia-calção não ter uma costura traseira, e a abertura foi feita por um corte no tecido, no centro das costas. A carcela da abertura do centro das costas, realizada no protótipo, é mostrada na figura 24. 
FIGURA 24 - ABERTURA TRASEIRA NO PROTÓTIPO DA SAIA-CALÇÃO E DETALHE (À DIREITA), MOSTRANDO A COLOCAÇÃO DE DOIS DOS COLCHETES
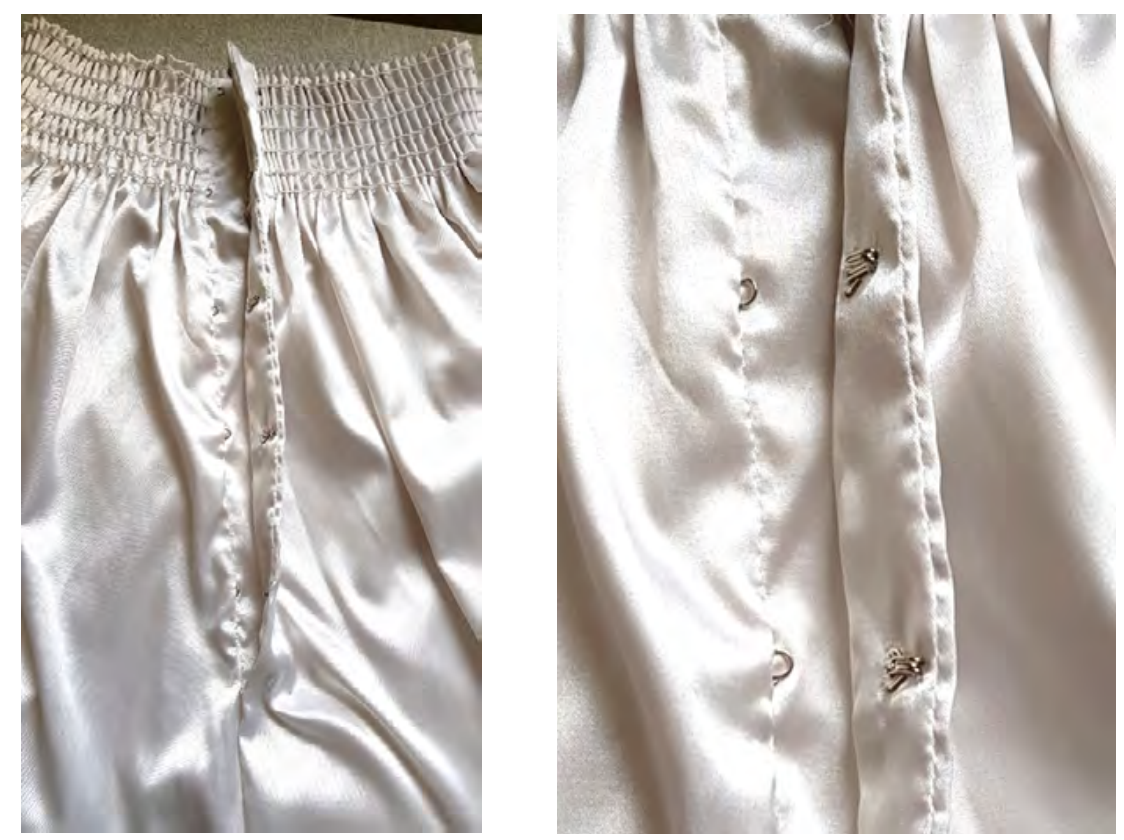

FONTE: Acervo do Núcleo de Traje de Cena, Indumentária e Tecnologia (USP).

Fotos: Isabel C. Italiano, 2020.

Na abertura para a passagem dos pés foi feita, à mão, uma barra estreita similar à bainha de lenço atual, de acordo com a bainha apresentada na publicação da Butterick (1911) e mostrada na figura 25.

FIGURA 25 - CONFECÇÃO DA BAINHA,

CONFORME INSTRUÇÕES DA PUBLICAÇÃO DE BUTTERICK, DE 1911

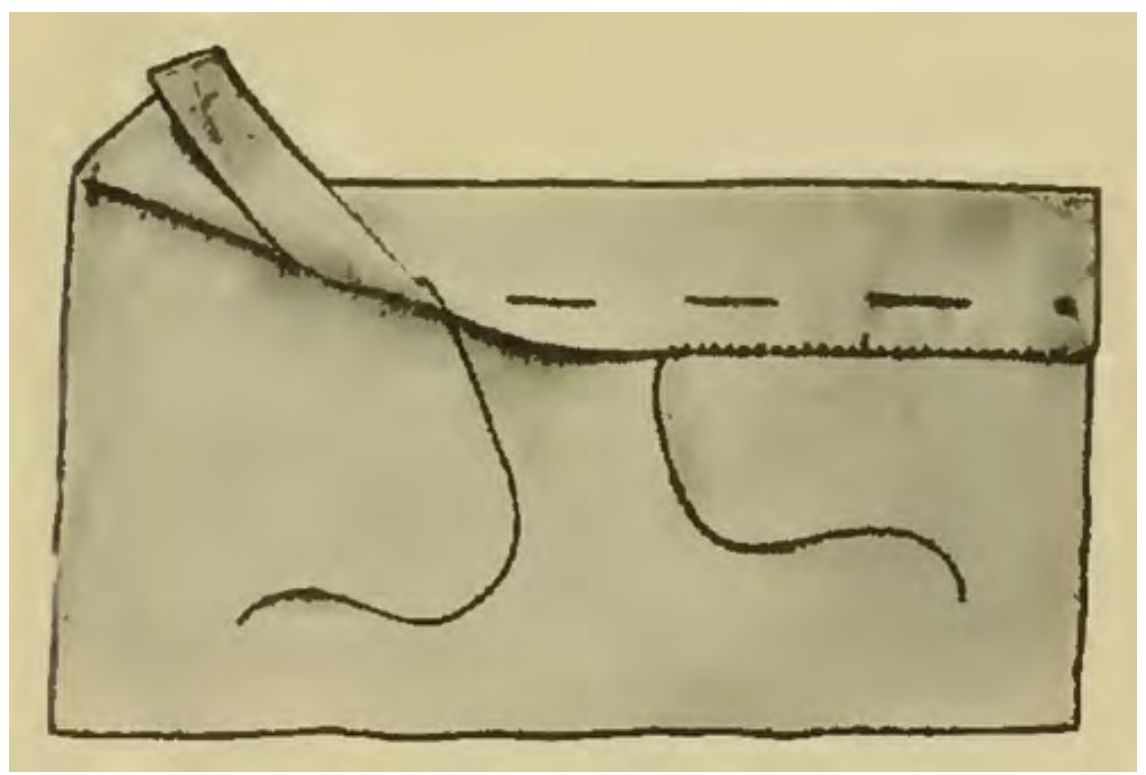

FONTE: BUTTERICK (1911, p. 6). 
Seguem-se, na figura 26, fotos do protótipo da saia-calção, desenvolvido a partir das instruções e modelagem do LACMA. Optou-se por não usar a faixa na cintura para que o detalhe do franzido ficasse aparente.

FIGURA 26 - VISÃO GERAL DO PROTÓTIPO DA SAIA-CALÇÃO
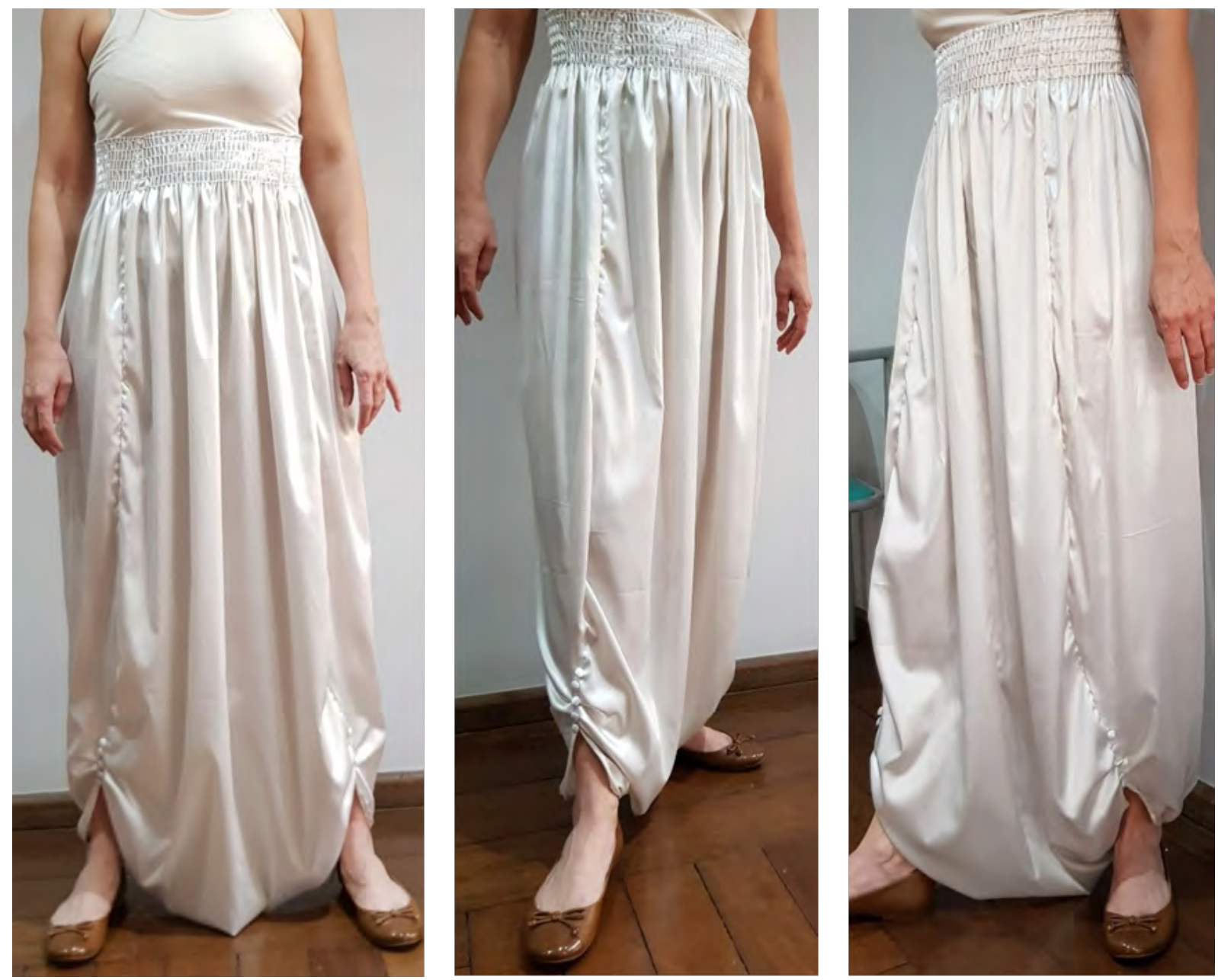

FONTE: Acervo do Núcleo de Traje de Cena, Indumentária e Tecnologia (USP).

Fotos: Isabel C. Italiano, 2020.

Alguns dos detalhes, como a abertura para a passagem dos pés e a traseira, são apresentados nas figuras 27 e 28. 

PROTÓTIPO DA SAIA-CALÇÃO
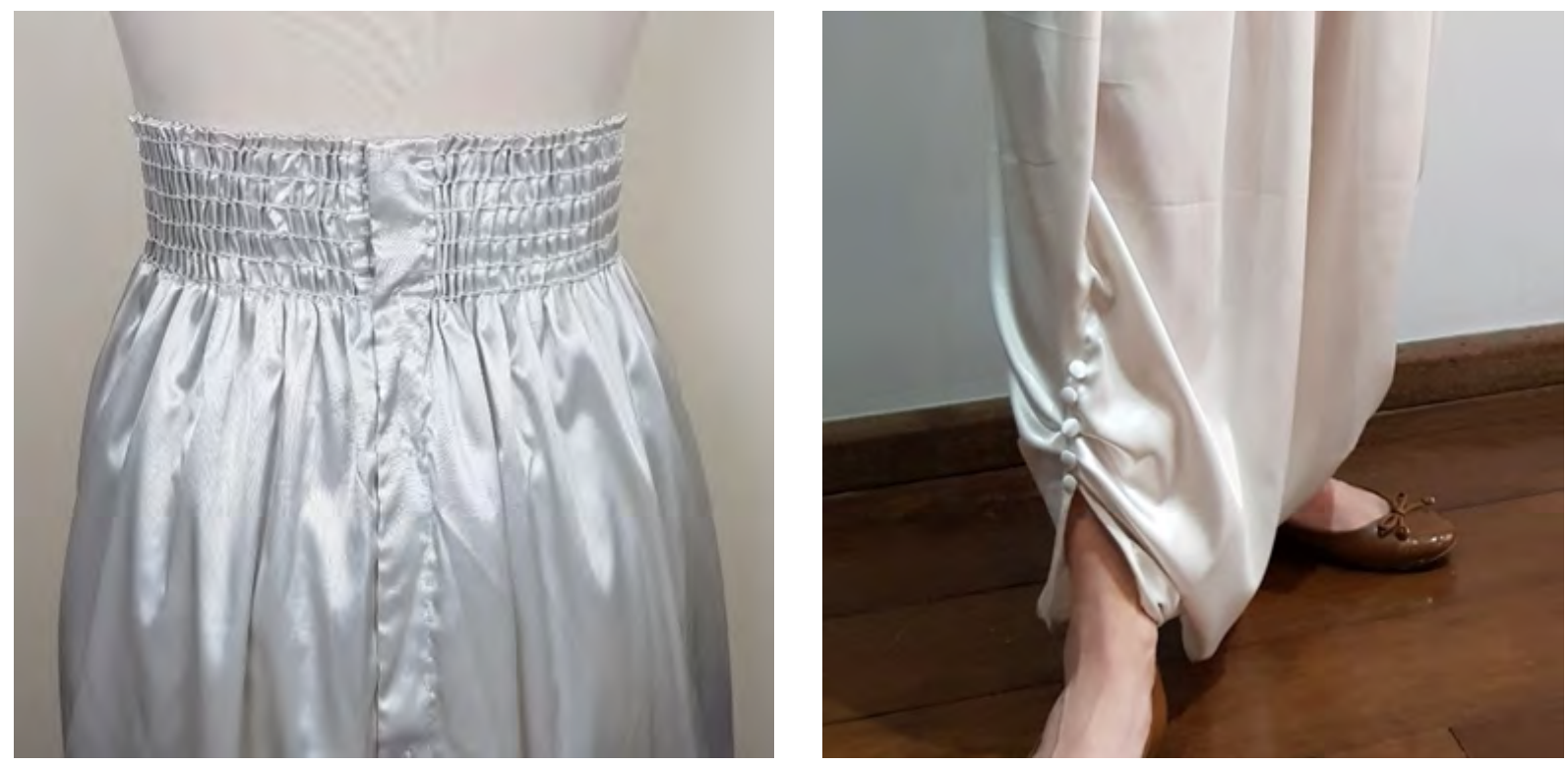

FONTE: Acervo do Núcleo de Traje de Cena, Indumentária e Tecnologia (USP).

Fotos: Isabel C. Italiano, 2020.

\section{Considerações finais}

O artigo apresenta relato sobre a criação, e a consequente introdução no Brasil, da jupe-culotte ou saia-calção. Essa peça do vestuário feminino, que provocou inúmeras discussões e opiniões controversas no início do século XX, é mostrada não só pelas mulheres protagonistas da vanguarda brasileira no período, que a vestiram com orgulho e ousadia, mas, também, pelas críticas de uma elite machista, por meio de charges e matérias publicadas em periódicos da época.

Além do panorama cultural e social que envolveu a adoção da saia-calção, o artigo apresenta a procura por sua modelagem e formas de construção em manuais técnicos publicados nas primeiras décadas do século XX. A busca mostrou-se infrutífera e o entendimento dos pesquisadores é de que uma peça do vestuário tão criticada pela sociedade não poderia ser parte de manuais de costura e modelagem que chegavam às casas das famílias ou fossem usados em escolas, para ensinar as aspirantes à costura, na época.

Um material de livre acesso, publicado pelo Los Angeles County Museum of Arts (LACMA), traz os detalhes e a modelagem de uma peça original, parte do acervo do museu, que serviu como ponto de partida para o estudo da modelagem e detalhes da jupe-culotte. Manuais de costura da época foram a base para as técnicas de construção usadas no desenvolvimento de um protótipo da saia-calção. Todo esse material possibilitou a recriação da peça original, do acervo do LACMA. 
Vale ressaltar que, ao se recriar roupas de vestuário histórico, é importante se basear nas técnicas e nos modos de fazer vigentes no período em que elas foram construídas e, portanto, é com esse rigor que o protótipo foi desenvolvido.

0 resultado é um trabalho que amplia o conhecimento desta área de pesquisa, tornando acessível a figurinistas, professores, estudantes e profissionais da área, novos subsídios para o estudo de trajes históricos, tanto no campo cultural e social, quanto no técnico.

Mademoiselle Paquin havia vociferado em 30 de março de 1911 que seria curta a existência da jupe-culotte. No entanto, logo no dia 3 de junho, na sua própria revista, foi publicado que a jupe-culotte

já apareceu na capital de Goiás. Exibiram-na quatro senhoritas daquela sociedade, acompanhadas de um cavalheiro, passeando pelas principais ruas da cidade e despertando no trajeto a curiosidade do público, que as aplaudiu. [...] Pelo que se lê, a jupe-culotte apareceu e firmou-se na capital do Estado de Goiás, até ulterior deliberação da Moda [...] (ILLUSTRAÇÃO PAULISTA, 1911, n. 22, p. 26)

No artigo da Vogue.com, Os altos e baixos das saias-calças, a autora aponta a curiosidade que a peça de Poiret e outros despertaram em 1911, em meio "a uma verdadeira guerra de chifons"7. Destaca a origem masculina do traje, um modelo bifurcado "uma meia-apropriação do traje interior do homem"8. Nos anos 1930, mostra os modelos propostos - e usados! - por Elsa Schiaparelli (1890-1973).

Já na década de 1960, Norman Norell (1900-1972), costureiro americano, não só reintroduziu a moda das jupes-culottes como ofereceu por empréstimo a qualquer designer, que desejasse usar, sua modelagem da roupa. "Os culottes", explica a Vogue, "logo entraram no swing do estilo jovem dos anos de 1960 e apareceram até mesmo nos desfiles de Twiggy" .

Não saíram mais de moda, em ciclos que passaram pelos anos 1970 (com criações de Perry Ellis), 1980 (quando Lady Di usou uma saia-calça, em 1981, para inaugurar as luzes de Natal na Regent Street) e voltaram nos anos de 2010, quando Hedi Slimane, na sua coleção de outono 2019 para Celine, criou "um desfile de peças muito bem-feitas que tratavam de estilo, não de moda"10, finaliza a Vogue.

Como se vê, Mademoiselle Paquin estava equivocada. Seria um alívio perceber que o preconceito e a violência contra a mulher tivessem se extinguido, mas não é o caso. Todo o preconceito estampado pela colunista Paquin contra a mulher continua ativo - e muito.

\footnotetext{
Disponível em: https://www.vogue.com/article/the-ups-and-downs-of-culottes-a-brief-history-from-paul-poiret-to-hedi-slimane. Acesso em: 9 mar. 2021.

8 Disponível em: https://www.vogue.com/article/the-ups-and-downs-of-culottes-a-brief-history-from-paul-poiret-to-hedi-slimane. Acesso em: 9 mar. 2021.

9 Disponível em: https://www.vogue.com/article/the-ups-and-downs-of-culottes-a-brief-history-from-paul-poiret-to-hedi-slimane. Acesso em: 9 mar. 2021.

10 Disponível em: https://www.vogue.com/article/the-ups-and-downs-of-culottes-a-brief-history-from-paul-poiret-to-hedi-slimane. Acesso em: 9 mar. 2021.
} 


\section{Referências}

A VIDA MODERNA. São Paulo, Armando de Queiroz Mondego, 1907-1922. 1911. Edição 85.

BUTTERICK. The Dressmaker: a complete book on all matters connected with Sewing and Dressmaking: from the simplest stiches to the cutting, making, altering, mending and caring for the clothes. New York: The Butterick Publishing Company, 1911.

ILLUSTRAÇÃO PAULISTA. São Paulo, Editora A. Machado \& Comp, 1910-1919. 1911. Edições $11,12,13$ e 22.

KODA, Harold; BOLTON, Andrew. Poiret. New York: The Metropolitan Museum of Art, 2007.

LAVER, James. A roupa e a moda: uma história concisa. São Paulo: Companhia das Letras, 1989.

WOMAN'S LOUNGING PAJAMAS. Los Angeles County Museum of Art, s.d. Disponível em: http://www.lacma.org/sites/default/files/FF_patterns_54.97.17axxxb.pdf. Acesso em: 10 ago. 2020.

UNDERTAKING THE MAKING. Los Angeles County Museum of Art, s.d. Disponível em: https://www.lacma.org/patternproject. Acesso em: 16 ago. 2020.

THORNTON, John. International System of Ladie's Garment Cutting. London: The Thornton Institute, [1911?]. 